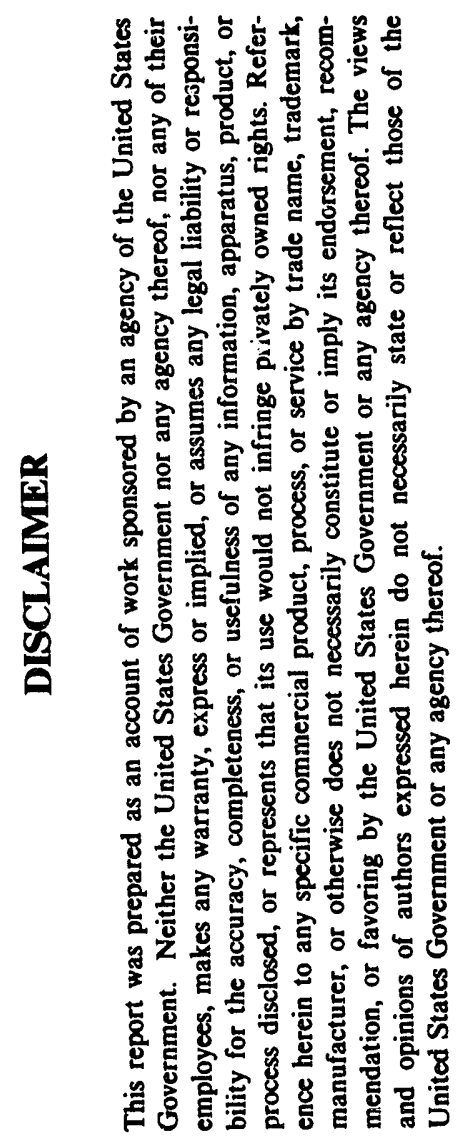

\title{
Report on Interim Storage of Spent Nuclear Fuel
}

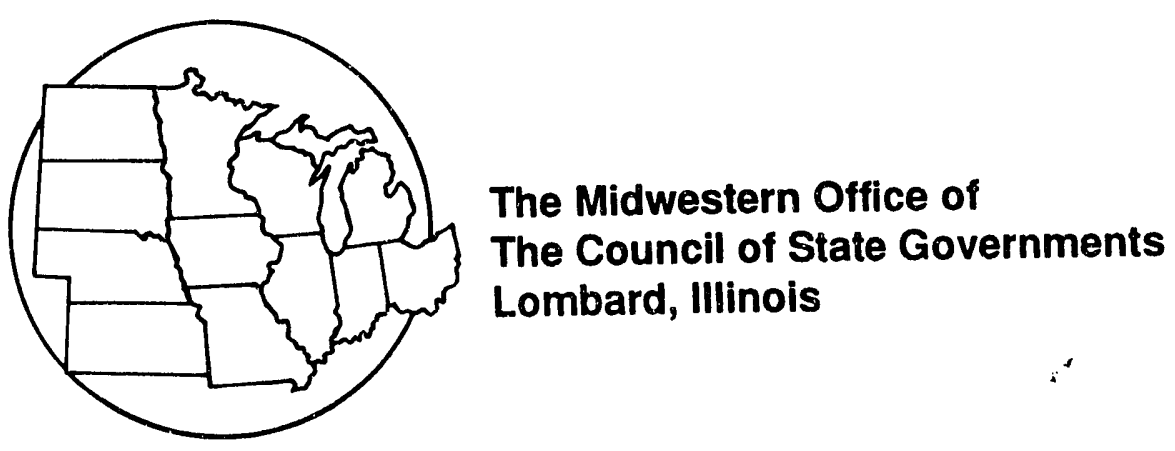




\section{The Council of State Governments}

For more than half a century, The Council of State Governments has served as a common ground for the states of the nation. The Council is a non-profit, state-supported and -directed service organization that provides research and resources, identifies trends, supplies answers and creates a network for legislative, executive and judicial branch representatives.

Through its national headquarters in Lexington, Kentucky, a state-federal office in Washington, D.C., and regional offices in New York, Atlanta, Chicago (Lombard) and San Francisco, CSG is dedicated to preserving the role of states in America's feoieral system.

The role of the Midwestern Office of CSC is to foster intergovernmental cooperation through the promotion of regional, as well as individual, state responses to common issues and challenges.

\section{Report on Interim Storage of Spent Nuclear Fuel}

This report was prepared with the support of the U.S. Department of Energy, Cooperative Agreement No. DE-FC01-89CH10402. However, any opinions, findings, conclusions or recommendations expressed herein are those of the author(s) and do not necessarily reflect the views of $\mathrm{DOE}$.

The purpose of the agreement, and reports issued pursuant to it, is to identify and analyze regional issues pertaining to the transportation of high-level radioactive waste and to inform Midwestern state officials with respect to technical issues and regulatory concerns related to waste transportation.

In addition to publishing reports related to the transportation of high-level radioactive waste, the Midwestern Office of CSG has compiled a reference library on radioactive waste transportation. All materials are available by loan. For more information, contact the Midwestern Office at 708/810-0210.

$$
\text { Prepared by: }
$$

Lisa R. Sattler, Policy Analyst Midwestern Office of

The Council of State Governments

641 E. Butterfield Road, Suite 401

Lombard, IL 60148-5651

(708) 810-0210 


\section{TABLE OF CONTENTS}

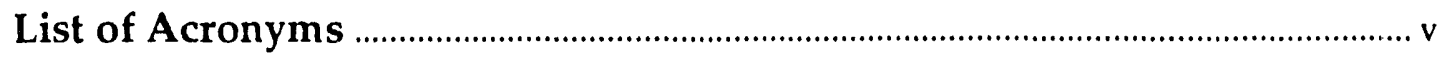

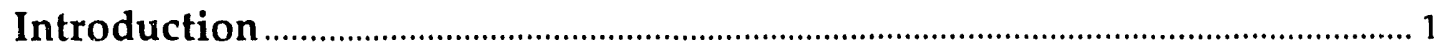

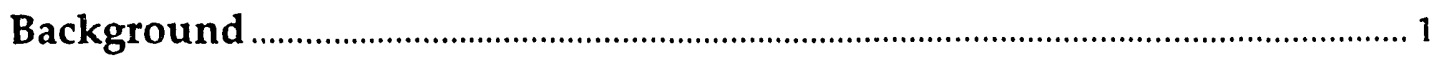

Spent-Fuel Storage Requirements ..................................................... 3

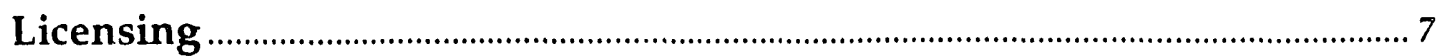

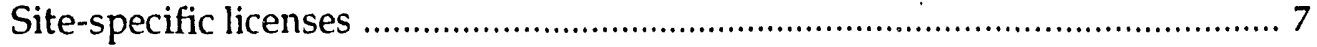

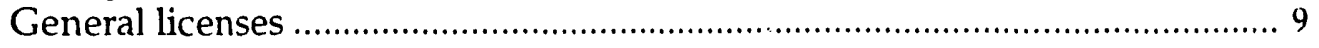

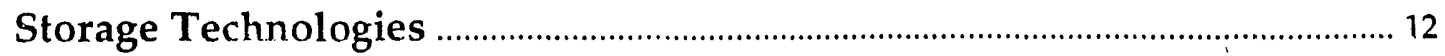

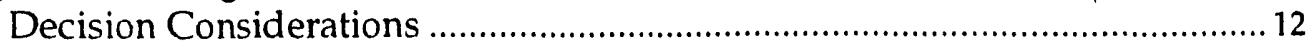

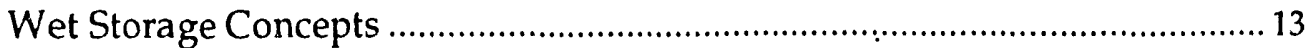

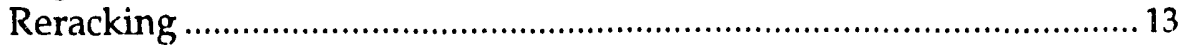

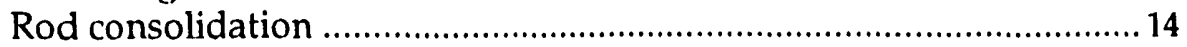

New pool construction .................................................................. 16

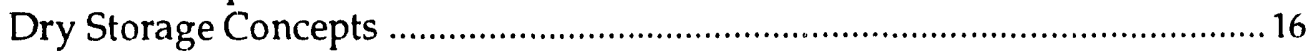

Modular concrete vaults ................................................................... 17

Horizontal concrete modules ........................................................... 19

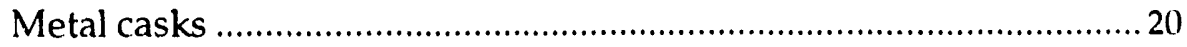

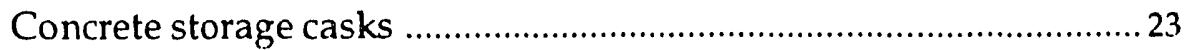

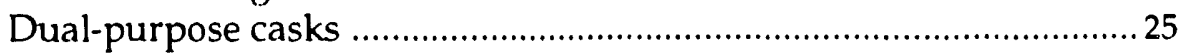

Multi-purpose canister systems ….............................................. 26

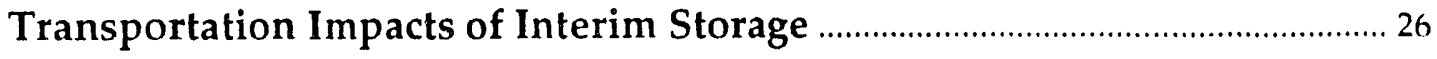

Interim Storage at Midwestern Reactors …........................................ 27

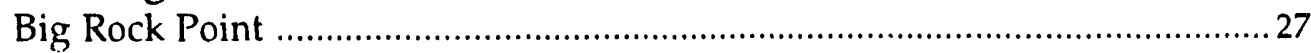

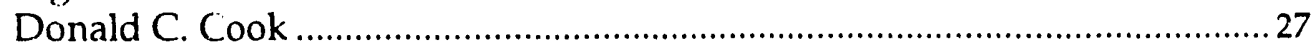

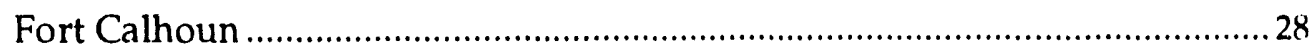

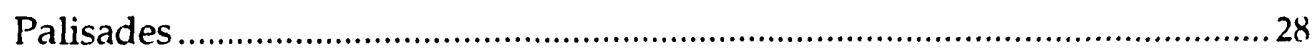

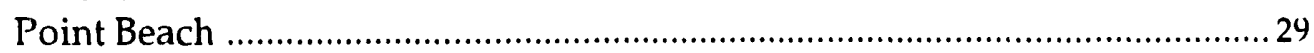

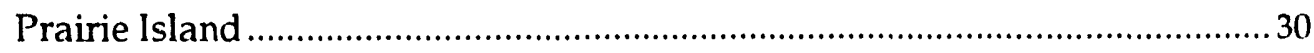

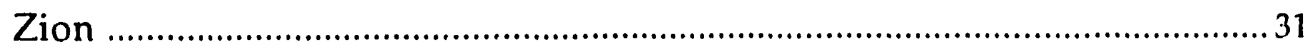

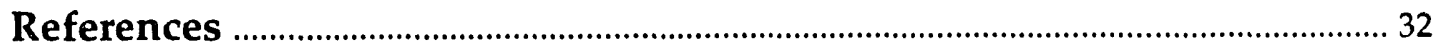

Appendix 1. Midwestern Commercial Nuclear Reactors .............................. A-1

Appendix 2. Detailed Additional Storage Needs in the Midwest ............. A-2

Appendix 3. Cumulative Additional Storage

Requirements by Utility 
Appendix 4. Additional Storage Needs at

Commonwealth Edison Reactors

Appendix 5. DOE Cost Estimates for Methods of Interim Storage A-8

Tables

1. Additional Spent-Fuel Storage Requirements 1992-2020 .............................. 4

2. Spent-Fuel Inventories and Storage Requirements at Midwestern Reactors 6

3. Licensing Requirements for the Independent Storage of Spent

Nuclear Fuel and High-Level Radioactive Waste (10 CFR 72)

4. Topical Safety Analysis Reports Submitted by Cask Vendors

5. Site-specific Licenses for ISFSIs Issued and Applications Under Review ...................................................... 10

6. Certificates of Compliance for Dry Spent-Fuel

Storage Casks and Applications Under Review ................................. 12

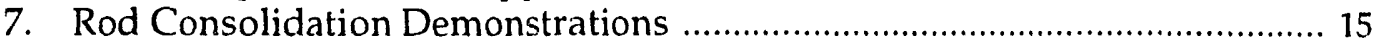

8. DOE Unit-Cost Estimates for

Additional Storage Requirements

\section{Figures}

1. Comparison of Additional Storage Needs:

Nationwide and the Midwest 5

2. Spent-fuel Inventories and Additional

Storage Requirements by Region 5

3. Modular Vault Dry Storage Facility at Fort St. Vrain ................................... 17

4. Generic Horizontal Modular Storage System (NUHOMS) .......................... 19

5. Conceptual Design for a Typical Metal Cask .................................................. 21

6. Conceptual Designs for Concrete Storage Casks ........................................... 23 


\section{LIST OF ACRONYMS}

$\begin{array}{ll}\text { BWR } & \text { Boiling-water Reactor } \\ \text { CANS } & \text { Coalition Against Nuclear Storage } \\ \text { CPC } & \text { Consumers Power Company } \\ \text { CP\&L } & \text { Carolina Power and Light Company } \\ \text { DOE } & \text { U.S. Department of Energy } \\ \text { EPRI } & \text { Electric Power Research Institute } \\ \text { FCR } & \text { Full core reserve } \\ \text { IMPC } & \text { Indiana-Michigan Power Company } \\ \text { INEL } & \text { Idaho National Engineering Laboratory } \\ \text { ISFSI } & \text { Independent spent-fuel storage installation } \\ \text { mrem } & \text { millirem } \\ \text { MPUC } & \text { Minnesota Public Utilities Commission } \\ \text { MRS } & \text { Monitored retrievable storage } \\ \text { MTHM } & \text { Metric tons of heavy metal } \\ \text { MTU } & \text { Metric tons of uranium } \\ \text { MVDS } & \text { Modular vault dry storage } \\ \text { NAC } & \text { Nuclear Assurance Corporation } \\ \text { NRC } & \text { U.S. Nuclear Regulatory Commission } \\ \text { NSP } & \text { Northern States Power Company } \\ \text { NUHOMS Nutech Horizontal Modular Storage } \\ \text { NWPA } & \text { Nuclear Waste Policy Act of 1982, as amended } \\ \text { OECD } & \text { Organization of Economic Cooperation and Development } \\ \text { PG\&E } & \text { Pacific Gas and Electric Company } \\ \text { PSCo } & \text { Public Service Company of Colorado } \\ \text { PSCW } & \text { Public Service Commission of Wisconsin } \\ \text { PWR } & \text { Pressurized-water Reactor } \\ \text { SAR } & \text { Safety Analysis Report } \\ \text { TSAR } & \text { Topical Safety Analysis Report } \\ \text { VSC } & \text { Ventilated Storage Cask } \\ \text { WEPCo } & \text { Wisconsin Electric Power Company } \\ \end{array}$




\section{INTRODUCTION}

The Report on Interim Storage of Spent Nuclear Fuel discusses the technical, regulatory, and economic aspects of spent-fuel storage at nuclear reactors. The report is intended to provide legislators, state officials, and citizens in the Midwest with information on spentfuel inventories, current and projected additional storage requirements, licensing, storage technologies, and actions taken by various utilities in the Midwest to augment their capacity to store spent nuclear fuel on site.

This report contains information derived from a number of references; however, it relies primarily on DOE's Final Version Dry Cask Storage Study (for information on storage technologies and associated costs) and Spent-Ful Storage Requirements 1991-2041 (for data on additional storage requirements). Interviews with representatives of various utilities contributed the bulk of the material discussed in the section on Midwestern reactors.

\section{BACKGROUND}

All methods of storing spent fuel share three basic requirements: each must provide a means of cooling irradiated fuel, a means of protecting workers from exposure to radiation, and a means of preventing the release of radioactivity (Resnikoff 318). Over the past four decades, spent fuel has been stored safely in pools of water (NEA 24). Water is the cooling and shielding medium of choice for three reasons (NEA 32):

- Its high thermal capacity facilitates the removal of heat from fuel assemblies.

- The transparency of water makes it relatively easy for operators to inspect and control the movement of fuel.

- Water is very good at shielding gamma and neutron radiation.

Moreover, water has traditionally been inexpensive, readily available, and recyclable with the use of heat exchangers or purifiers (NEA 32).

In the early days of nuclear-power development, storage pools were designed under the assumption that discharged fuel would be cooled for six months then shipped off site for reprocessing. As a consequence, many pools were capable of holding only 1 -and $-1 / 3$ reactor cores - that is, one or two annual discharges of fuel $(1 / 3$ to $2 / 3$ of a reactor core) plus room for a full core (known as "full core reserve" or FCR) in the event that the reactor needed to be emptied to make repairs (Carter 7; Resnikoff 40). However, with the ban on reprocessing

' instituted under the Carter Administration and the subsequent demise of the commercial reprocessing industry in the U.S., utilities began accumulating spent fuel in quantities that exceeded the design capacity of their storage pools. To alleviate the growing storage problem, new reactors were designed with larger pools and higher density spent-fuel storage racks were installed in existing pools. Despite the greater capacity, though, many reactors still face the loss of FCR by the end of this century - a situation largely attributable to the failure of the federal government to develop in a timely manner a program for disposing of this fuel.

The Nuclear Waste Policy Act (NWPA) of 1982 charged the U.S. Department of

'Maintaining FCR is not a technical requirement of the U.S. Nuclear Regulatory Commission (NRC), however most utilities provide FCR capability for their reactors (DOE 1991, 2.1). 
Energy (DOE) with developing and overseeing a program to dispose of high-level radioactive waste and spent fuel from commercial nuclear reactors. Under the provisions of the act, DOE would begin accepting spent fuel for disposal in a geologic repository starting January 31,1998 . Subsequent revisions to the waste-management program pushed the opening date of the repository to 2010; nonetheless, DOE remains committed to meeting the 1998 deadline for accepting spent fuel (see DOE 1989b).

The department planned to achieve this goal by constructing and operating a monitored retrievable storage (MRS) facility, which would temporarily store spent fuel until the repository comes on line. While the NWPA provided DOE with the authority to build an MRS facility, the Nuclear Waste Policy Amendments Act of 1987 added several conditions to the development of the facility (\$142[b]). Construction of the MRS facility, for instance, cannot begin until a construction license has been issued for the repository (\$148[d][1]). Furthermore, the act limited the amount of spent fuel that can be stored at the facility to 10,000 metric tons of uranium (MTU) prior to repository operation and 15,000 MTU afterwards (\$148[d]|3-4]). However, DOE intended to develop an MRS facility by 1998 through the efforts of the U.S. Nuclear Waste Negotiator, who is authorized to identify a volunteer host and negotiate an MRS agreement that is not linked to the repository schedule.

DOE has consistently maintained that a temporary-storage facility will enable it to achieve its 1998 deadline for accepting spent fuel. Critics of DOE's plans for the MRS facility argue that, even if Congress were to pass legislation rescinding tile links between the MRS facility and repository development, DOE would not be able to site and construct a temporary storage facility in time to begin accepting spent fuel for storage in 1998.

With both permanent disposal and federal off-site storage unavailable as near-term options, utilities are faced with the burden of storing spent fuel in the interim. In the NWPA, Congress found that the owners and operators of civilian nuclear reactors have the primary responsibility for providing interim storage. It also found, however, that the federal government held some responsibility for helping utilities solve their storage problems (\$131|a || 12 )). Toward this end, Congress authorized the federal government to provide up to 1,900) MTU of spent-fuel storage capacity to "prevent disruptions in the orderly operation of any civilian nuclear power reactor that cannot reasonably provide adequate . . . storage capacity" (\$131[b|[2]). To store spent fuel under the Federal Interim Storage program, eligible utilities were required to enter into contracts with DOE and to pay the costs of storage. On January 1,1990 , the deadline for entering into contracts passed without any utilities having signed up.

The NWPA also authorized the federal government to fund and participate in the research and development of dry storage technologies (\$218). The goal of this provision was to develop dry storage technologies that could be used at reactor sites without the need for licensing on a site-by-site basis. Section 133 of the NWPA directed the NRC to establish procedures for licensing such technologies (for more information, see the section on licensing). In addition, in the 1987 amendments to the NWPA, Congress directed DOE to study and evaluate the use of dry cask storage technology for at-reactor storage of spent fuel $(\$ 5604) .^{2}$

In its 1984 "Waste Confidence Decision," the NRC reported its finding that spent fuel can be stored in spent-fuel pools or in on-site independent spent-fuel storage installaStorage Study.

${ }^{2}$ DOE complied with this provision in 1989 with the release of the Final Version Dry Cask 
tions (ISFSIs) without significant environmental impacts for at least 30 years beyond the expiration of a reactor's operating license (NRC 1990, 38509). In 1990, the commission largely reaffirmed this finding, changing only the length of time for which spent fuel may be safely stored to "at least 30 years beyond the licensed life for the plant (which may include the term of a revised or renewed license)" (NRC 1990, 38509). At-reactor storage of spent fuel thus does not significantly threaten either the environment or public health and safety. However, inadequate at-reactor storage capacity can create potential problems for utilities in that operation of the plant can be adversely affected if there is not adequate spent-fuel storage capacity to allow planned refueling of the reactor core.

\section{SPENT-FUEL STORAGE REQUIREMENTS}

Several factors influence the amount of additional storage capacity required to accommodate spent-fuel quantities. A reactor's annual rate of fuel discharge determines how many assemblies will be added to storage each year. This rate, in turn, is affected by the average level of discharged fuel burnup - that is, the amount of energy obtained per unit of fuel. In addition, the operating efficiency of nuclear plants affects the rate at which fuel is discharged. The capacity of spent-fuel storage pools also affects additional storage requirements. ${ }^{3}$ Currently, the total capacity of existing and planned pools amounts to about $60,000 \mathrm{MTU}$, assuming widespread reracking of pools (Wood 1017). (For further information on reracking, see the section on wet storage technologies.)

If the current trend toward higher burnup continues, annual discharge rates for individual reactors will decline. However, because more reactors are expected to come on line in the future, the aggregate amount of fuel discharged on a national scale is expected to remain fairly constant at close to 2,000 MTU per year over the next two decades. By the time the last spent fuel is removed from existing and planned reactors in the United States, approximately $87,000 \mathrm{MTU}$ of spent fuel will have been generated (Wood 1016).

Eventually all the spent fuel stored at reactors will be removed and shipped to DOE facilities for storage or disposal. The date acceptance begins, the rate at which it takes place, and the allocation of acceptance rankings all will have an impact on additional storage requirements. Even under the most optimistic scenario, DOE will not begin to accept spent fuel until 1998. By the beginning of that year, at least 22 reactor pools are projected to lose FCR, with additional storage requirements reaching over 1,600 MTU of spent fuel. By the end of this century, additional storage requirements for the 33 reactor pools projected to lose FCR will reach almost 3,000 MTU (DOE 1991, Table B.4b).

When DOE begins to accept spent fuel, it will do so following a policy of "oldest fuel first." In other words, the utilities that own the oldest fuel will receive priority for acceptance of their spent fuel. This policy was established to provide equity for utilities that have been storing spent fuel the longest. Because these utilities will not necessarily be the ones in greatest need of storage space, the initiation of federal acceptance of spent fuel will not be the most efficient way to relieve the storage problems faced by utilities. In fact, it is estimated that every three units of additional federal storage capacity will open up only one unit of at-reactor storage. Yet because utilities are allowed to trade their rankings, many experts believe transactions between utilities will generate an efficient allocation of acceptance rights (Wood 1020).

${ }^{3}$ Estimates of spent fuel storage requirements generally do not include dry storage capacity in calculating on-site capacity. 
During the first decade of MRS operation, DOE plans to accept a maximum of 900 MTU of spent fuel annually. The acceptance rates for the first two years of MRS operation will be lower, at 400 and $600 \mathrm{MTU}$, respectively (DOE 1993a, 4). According to DOE's own estimates, however, almost 2,000 MTU in additional storage capacity will be required by the end of 1998 (DOE 1991, Table B.4b). Therefore, even if DOE does manage to meet its deadline for the MRS facility, additional storage space will be necessary during 1998 for at least $1,500 \mathrm{MTU}$ of spent fuel.

Nationwide, additional at-reactor storage requirements in 1992 amounted to approximately $300 \mathrm{MTU}$ of spent fuel (Table 1). Storing this relatively small amount of material can be managed by transferring fuel from a facility that is short of space to reactor pools owned and operated by the same utility (Figure 1).4 Between 1992 and 2020, intra-utility transshipment can reduce the shortfall in storage space; however, with or without transshipment, by 2020, additional spent-fuel storage requirements are projected to reach about 20,000 MTU. Much of this growth is expected to take place between 2006 and 2014, when storage requirements are projected to increase at an average rate of over 1,000 MTU per year. In 2008, the amount of spent fuel requiring storage will exceed the NWPA's limit of 10,000 MTU to be placed in the MRS facility prior to operation of the repository. With intrautility transshipment, the statutory limit will not be reached until the year after the repository is scheduled to open. In 2010, the year DOE plans to begin repository operations, additional storage requirements in the United States are projected to reach $12,215 \mathrm{MTU}$; intra-utility transshipment has the potential to reduce this amount to $9,600 \mathrm{MTU}$.

In 1990, over 27 percent of the nation's accumulated spent fuel was stored at reactor

\begin{tabular}{|c|c|c|c|c|}
\hline \multirow[b]{3}{*}{ Year } & \multicolumn{2}{|c|}{ National } & \multicolumn{2}{|c|}{ Midwest } \\
\hline & Without & With & Without & With \\
\hline & Transshipment & Iransshipment & Iransshipment & Iransshipment \\
\hline$\overline{1992}$ & 294 & 18 & 18 & 18 \\
\hline 1994 & 647 & 155 & 110 & 110 \\
\hline 1996 & 1,192 & 530 & 289 & 230 \\
\hline 1998 & 1,962 & 1,051 & 561 & 434 \\
\hline 2000 & 2,901 & 1,852 & 888 & 694 \\
\hline 2002 & 4,354 & 2,969 & 1,294 & 1,013 \\
\hline 2004 & 5,932 & 4,246 & 1,798 & 1,374 \\
\hline 2006 & 7,802 & 5,820 & 2,314 & 1,732 \\
\hline 2008 & 10,123 & 7,716 & 2,833 & 2,121 \\
\hline 2010 & 12,215 & 9,600 & 3,429 & 2,670 \\
\hline 2012 & 14,367 & 11,884 & 3,944 & 3,360 \\
\hline 2014 & 16,476 & 14,271 & 4,421 & 3,952 \\
\hline 2016 & 18,033 & 16,160 & 4,730 & 4,433 \\
\hline 2018 & 19,418 & 17,798 & 5,022 & 4,864 \\
\hline 2020 & 20,897 & 19,538 & 5,387 & 5,291 \\
\hline
\end{tabular}

Source: DOE 1991, Tables B.4a, B.4b, C.2a, C.2b.

${ }^{4} D O E^{\prime}$ s estimates of additional storage requirements assume transshipment is used only for pool storage; that is, they assume utilities will not ship their spent fuel to a site with additional dry storage capacity (DOE 1991, 3.2). It should be noted that problems have arisen and may arise with regard to utilities gaining approval for transshipment of spent fuel. 


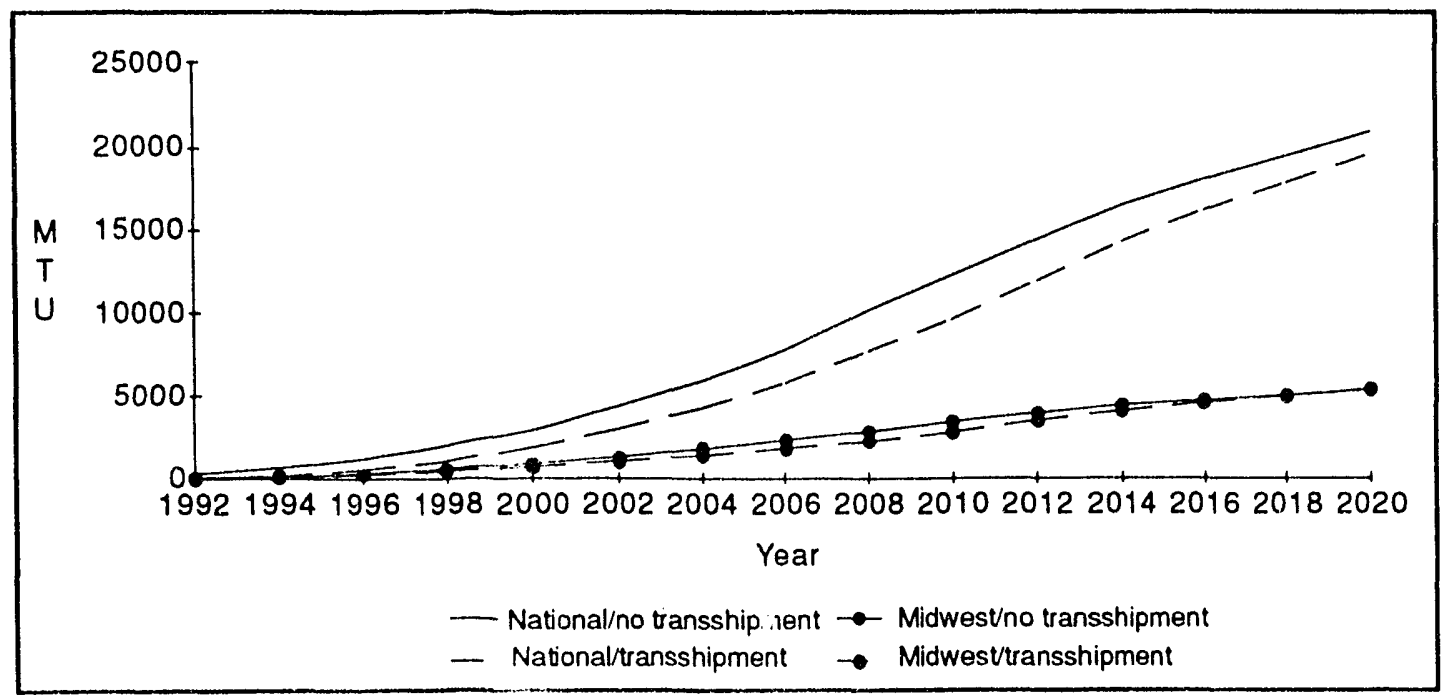

Figure 1. Comparison of Additional Storage Needs: Nationwide and the Midwest

sites in the Midwest (Figure 2). Between 1992 and 2020, spent-fuel storage requirements in the Midwest are expected to rise by about $190 \mathrm{MTU}$ per year on average, with or without transshipment (see Figure 1). In 1998, Midwestern utilities will need between 430 and 560 MTU of additional storage space, depending on the extent to which transshipment is employed. By 2010, additional storage requirements in the Midwest are projected to reach between 2,670 and 3,430 MTU.

These aggregate data do not adequately describe the situations at individual reactors. By 1998, seven of the 25 reactor pools in the Midwest are projected to lose FCR; all but four of the existing pools are expected to run out of space before the repository is scheduled to open (Table 2). Transshipment can alleviate this storage crunch only to a limited extent. Commonweal th Edison Company of Illinois is the only Midwestern utility for which transshipment is considered a viable option (see Appendix 4). Commonwealth Edison's

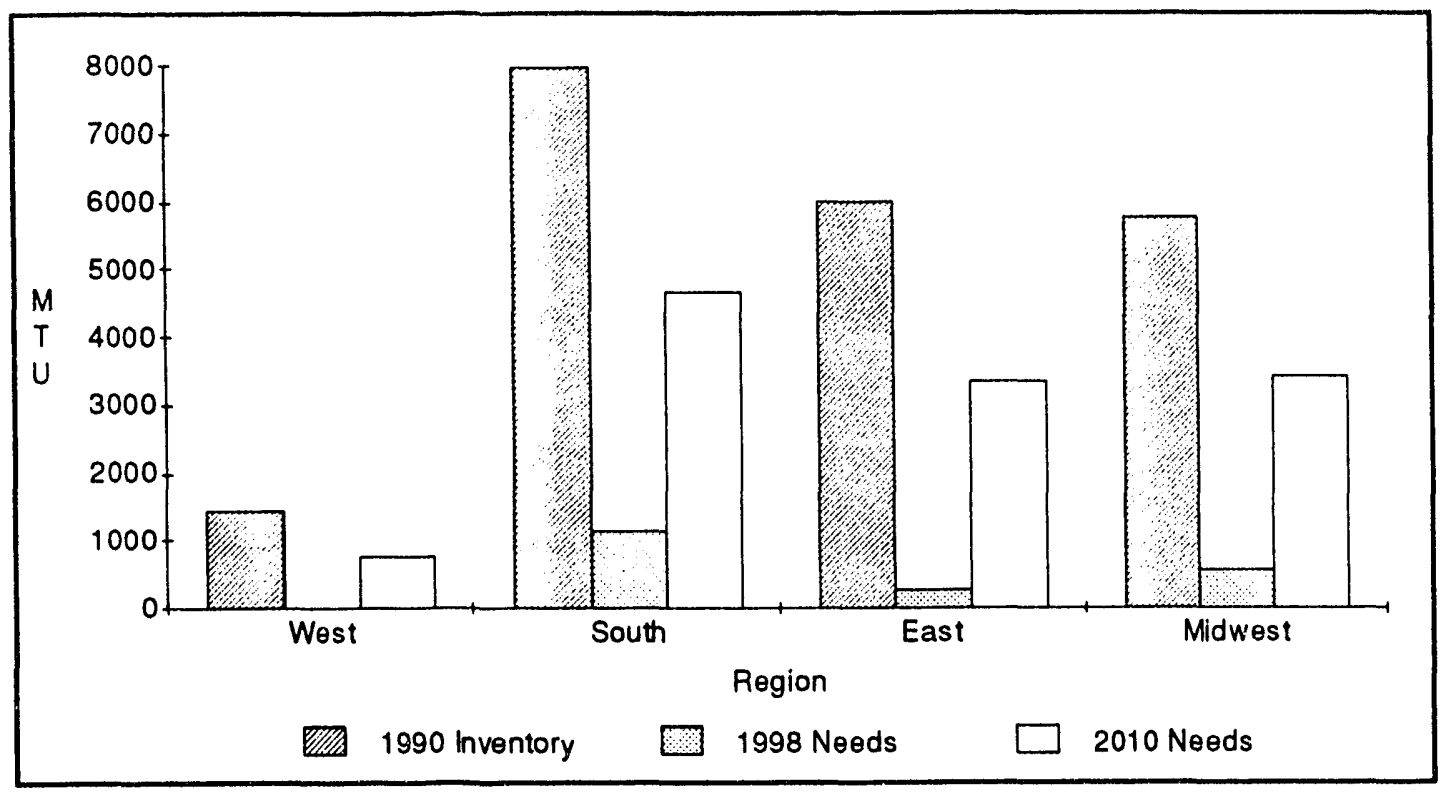

Figure 2. Spent-fuel Inventories and Additional Storage Requirements by Region 


\begin{tabular}{|c|c|c|c|c|c|c|c|c|}
\hline \multirow[b]{3}{*}{ Beactor Pool } & \multirow[b]{3}{*}{ Iype } & \multirow{3}{*}{$\begin{array}{l}\text { Year } \\
\text { lose } \\
\text { FCB }\end{array}$} & \multirow{2}{*}{\multicolumn{2}{|c|}{1990 Inventory }} & \multicolumn{4}{|c|}{ Projected Storage Requirements $^{\mathbf{a}}$} \\
\hline & & & & & 19 & & & \\
\hline & & & Assem. & MTU & Assem & MTU & Assem. & MTU \\
\hline Big Rock 1 & $\overline{B W R}$ & $\overrightarrow{1996}$ & 274 & 36 & 57 & 7 & 109 & 14 \\
\hline Braidwood $1 \& 2^{\circ}$ & PWR & 2018 & 236 & 101 & 0 & 0 & 0 & 0 \\
\hline Byron $1 \& 2^{\circ}$ & PWR & 2016 & 424 & 180 & 0 & 0 & 0 & 0 \\
\hline Callaway 1 & PWR & 2006 & 364 & 162 & 0 & 0 & 210 & 90 \\
\hline Clinton 1 & BWR & 2005 & 384 & 71 & 0 & 0 & 676 & 125 \\
\hline Cook $1 \& 2^{\circ}$ & PWR & 1997 & 1,367 & 602 & 136 & 59 & 1,122 & 486 \\
\hline Cooper Station & BWR & 2007 & 456 & 84 & 0 & 0 & 357 & 65 \\
\hline Davis-Besse 1 & PWR & 1998 & 328 & 154 & 23 & 11 & 297 & 140 \\
\hline Dresden 1 & BWR & ... & 683 & 70 & 0 & 0 & 0 & 0 \\
\hline Dresden 2 & BWR & 2001 & 1,954 & 352 & 0 & 0 & 751 & 125 \\
\hline Dresden 3 & BWR & 2002 & 1,752 & 318 & 0 & 0 & 653 & 109 \\
\hline Duane Arnold & BWR & 1999 & 1,048 & 194 & 0 & 0 & 609 & 101 \\
\hline Fermi 2 & BWR & 2001 & 220 & 40 & 0 & 0 & 1,286 & 234 \\
\hline Fort Calhoun & PWR & $1 \subseteq 95$ & 477 & 172 & 65 & 23 & 347 & 124 \\
\hline Kewaunee & PWR & 1299 & 540 & 209 & 0 & 0 & 362 & 137 \\
\hline LaCrosse & BWR & -.. & 333 & 38 & 0 & 0 & 0 & 0 \\
\hline LaSalle $1 \& 2^{c}$ & BWR & 2022 & 1,304 & 239 & 0 & 0 & 0 & 0 \\
\hline Monticello & BWR & 2008 & 446 & 80 & 0 & 0 & 128 & 22 \\
\hline Palisades & PWR & 1992 & 656 & 262 & 248 & 99 & 626 & 250 \\
\hline Perry 1 & BWA & 2009 & 544 & 100 & 0 & 0 & 254 & 45 \\
\hline Point Beach $1 \& 2^{\circ}$ & PWR & 1993 & 1,081 & 425 & 310 & 112 & 1,036 & 370 \\
\hline Prairie Island $1 \& 2^{b}$ & PWR & 1993 & 1,082 & 412 & 347 & 123 & 1,057 & 372 \\
\hline Quad Cities $1 \& 2^{c}$ & BWR & 2008 & 3,692 & 683 & 0 & 0 & 407 & 71 \\
\hline Wolf Creek & PWR & 2012 & 256 & 118 & 0 & 0 & 0 & 0 \\
\hline Zion $1 \& 2^{\circ}$ & PWR & 1996 & 1,448 & 661 & 278 & 127 & 1,200 & 549 \\
\hline Totals: & & & 21,349 & 5,763 & 1,464 & 561 & 11,487 & 3,429 \\
\hline
\end{tabular}

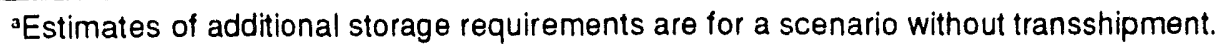

'Reactors share one pool.

'Reactor pools are connected.

Source: DOE 1991, Tables B.2a, B.2b, B.4a, B.4b.

Braidwood, Byron, and LaSalle reactor pools are expected to maintain FCR until at least 2016, therefore they would be capable of relieving the storage burden faced by the Dresden and Zion plants. ${ }^{5}$ Taking full advantage of transshipment would push back the first year of additional storage requirements from 1996 to 2009, a gain of 13 years. By 2020, however, the difference in Commonwealth Edison's additional storage requirements with and without transshipment is projected to be slightly less than $100 \mathrm{MTU}$, or just less than 7 percent of the total amount of spent fuel the utility will have in additional storage.

The preceding estimates do not assume transfer of spent fuel to DOE facilities, which can be an important factor in individual cases. Based on DOE's annual acceptance allocation, over 2,200 MTU will be removed from Midwestern reactor pools during the first 10 years after DOE begins accepting spent fuel for storage or disposal (DOE 1993a, Tables A.1-A.10). The extent to which the initiation of acceptance alleviates the need for additional at-reactor storage, however, depends upon both the starting date and the relative rank of the various sites with respect to acceptance priority. Even with an optimistic starting date of

${ }^{5}$ DOE's estimates assume PWR fuel from Zion would be transshipped to Braidwood and Byron, while LaSalle would receive BWR fuel from Dresden units 2 and 3. 
1998, the reactor pools at the Palisades, Point Beach, Prairie Island, Big Rock, Zion, and Fort Calhoun plants will all have either added on-site storage capacity or lost FCR by the time DOE removes fuel from these sites.

Only a few Midwestern reactors stand to benefit from the early initiation of acceptance. For example, close to $430 \mathrm{MTU}$ of spent fuel will be removed from the reactor pools at the Dresden plant during the first 10 years of acceptance. If acceptance does begin in 1998, Commonwealth Edison may avoid having to provide additional storage for its BWR reactors. The company may also be able to postpone construction of a PWR storage facility until 2013. Timely acceptance may also postpone the date at which the reactor pools at the Cooper, Davis-Besse, and Monticello plants lose FCR.

\section{LICENSING}

Nearly all expansions of on-site storage capacity require some type of licensing

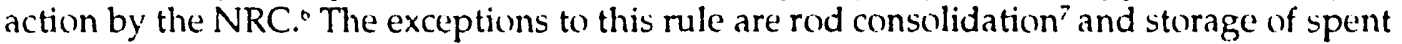
fuel in quantities small enough to remain within the limits specified in the plant's operating license (see 10 CFR 50.59[a]) (DOE 1989a, 1-22). Pool storage of spent fuel in excess of the licensed limit, however, must first receive approval from the NRC in the form of an arnendment to the plant's operating license. Because amending a license constitutes a formal NRC licensing action, an opportunity for public hearing must be provided in situations in which a utility wishes to expand on-site storage capacity (10 CFR 50.91). ${ }^{8}$ In the past, states and local environmental groups have created significant delays in licensing by intervening in the amendment process (see, for instance, the discussion of reracking the Diablo Canyon storage pools in the section on wet storage technologies).

Unlike storage in a spent-fuel pool, a dry storage installation is not considered fundamental to the operation of a nuclear power plant; rather it is viewed as an additional facility entirely independent of the rest of the site. As a result, licensing for storage expansions using dry technologies involves a different and often more involved process. The requirements for licensing ISFSIs are contained in 10 CFR 72, "Licensing Requirements for the Independent Storage of Spent Nuclear Fuel and High-Level Radioactive Waste" (Table 3). Two different types of licenses are available to utilities seeking to construct ISFSIs: a license specific to the proposed site and a general license to use NRC-certified storage casks.

Site-specific licenses. The regulations for site-specific licenses are found in 10 CFR 72, Subparts B-I. Site-specific licensing is a one-step process, with NRC approval extending to both construction and operation of the ISFSI. ${ }^{9}$ An environmental assessment is required

"States often have their own requirements for permitting or approval of storage expansions. For example, see the discussion of the ISFSIs at the Palisades and Point Beach reactors in the section on Midwestern reactors.

${ }^{7}$ Rod consolidation involves reducing the volume of spent-fuel assemblies in storage by spacing the fuel rods more closely together. For more information, see the section on wet storage technologies.

${ }^{8}$ Required by $\$ 134$ of the NWPA.

${ }^{9}$ Under 10 CFR 72.40 (b), the NRC can deny a license request if facility construction commences before the commission has completed an environmental review. There are cases in which construction has begun after the environmental review process but before a license is issued. In such instances, construction has been at the risk of the applicants (Haughney 1993, 1). 
as part of the licensing process (Haughney 1992,5). Once issued, a license is valid for up to 20 years and is renewable after review (\$72.42).

Utilities interested in applying for site-specific licenses generally meet with NRC staff to discuss their application and to identify particular issues that should be addressed. A recent review of the NRC's experience with licensing ISFSIs cited $20 \mathrm{common}$ problems with ISFSI applications, ranging from insufficient supporting documentation to failure to comply with specific regulations (Sturz et al. 225-27). The authors of the report concluded that their experience with licensing reviews demonstrates "the importance of early discussion with the NRC staff before extensive effort is expended on the application" (Sturz et al. 221).

Upon receiving an application for a site-specific license, the NRC assigns it a docket number and files a notice of docketing in the Federal Register (\$72.16). The NRC also files (either separately or in conjunction with the docketing notice) a notice of proposed action and opportunity for hearing or, if a hearing is deemed necessary, a notice of public hearing $(\$ 72.46)$. As mentioned previously, the hearings provision is often a source of lengthy delays in the licensing process. To facilitate the process, the NRC may enter into Stipulation Agreements with states. These agreements bring together the utility, the state, and NRC staff to exchange information and resolve potential state concerns (Sturz 4). Stipulation Agreements have been reached as part of the licensing process for ISFSIs at the Calvert Cliffs, Fort St. Vrain, and Prairie Island plants (Sturz 4-5).

An application for a site-specific license comprises an enormous amount of information. As part of the general requirements, the applicant must provide reasonable assurance that it is and will continue to be financially capable of carrying out the activities related to we licensing application, including constructing, operating and decommissioning the ISFSI $(\$ 72.22)$. In addition, the applicant must demonstrate that it has the technical qualifications to engage in these activities, including a commitment to maintain a trained and certified staff prior to the receipt of spent fuel for storage (\$72.28).

The Safety Analysis Report (SAR) provides technical information on the facility's design and operation and constitutes the heart of the application. The minimum information to be included in the SAR is detailed in 10 CFR 72.24. The SAR must include a description and safety assessment of the site. Enumerated in Subpart E, the siting criteria require a minirnum distance of 100 meters between the waste handling and storage facilities and the nearest boundary of the control area (\$72.106). In addition, radiation dose equivalents are 
limited to 25 mrem (whole body) per year under normal operating conditions and 5 rem (whole body or any organ) per occurrence in the event of an accident (\$72.104, \$72.106).

The SAR must also include detailed information on the design of the ISFSI, adhering to the design criteria of Subpart F. Specific plans for addressing quality assurance (Subpart $G$ ), physical protection (Subpart H), and the training and certification of personnel (Subpart I) are also included in the SAR. The report also must contain an analysis of the facility's safety systems to assess the potential impact operation of the ISFSI will have on public health and safety.

To facilitate the licensing process, and thereby to make their products more attractive to potential buyers, vendors of dry-storage systems often submit topical safety analysis reports (TSARs) for review by NRC staff. A TSAR describes the design of the dry-storage system and the purposes for which it is to be used. Information regarding the technology must be supported by a safety analysis report along with test data. Once it has been approved by the NRC,10 a TSAR may be referenced in a utility's SAR for a site-specific licensing application, thus reducing the time needed to complete the licensing process (DOE 1989a, 1-22). As of December 1992, 10 TSARs had been approved, and two applications were pending (Table 4).

Each application for a site-specific license is subjected to an environmental review and a safety review (Haughney 1992, 6). After these are completed (and, if a public hearing has been conducted, after a decision has been issued), the NRC will approve the licensing request, provided the application meets all the conditions specified in Subpart C (\$72.40). As of December 1992, five ISFSIs had received site-specific licenses and three more applications were under consideration (Table 5).

General licenses. In the NWPA, Congress tried to streamline the licensing of onsite storage facilities for spent fuel. Section 218(a) of the NWPA directed the Secretary of Energy to "establish a demonstration program ... for the dry storage of spent nuclear fuel at civilian nuclear power reactor sites...." The objective of this demonstration program was to develop one or more storage technologies that the NRC, through a rulemaking process, could "approve for use at the sites of civilian nuclear power reactors without, to the maximum extent practicable, the need for additional site-specific approvals by the Commission" (NWPA \$218[a]). To ensure the development of such rules, Congress required the NRC to "establish procedures for the licensing of any technology approved by the Commission under section [218(a)] for use at the site of any civilian nuclear power reactor" (NWPA \$133). These procedures were intended to supplement and not to preclude site-specific licensing."

On July 18, 1990, the NRC published its final rule on general licenses in the Federal Register. The ruling established a new Subpart K within 10 CFR 72, which is entitled "General License for Storage of Spent Fuel at Power Reactor Sites." Section 72.210 of the new regulations issued a general license for storing spent fuel in an on-site ISFSI to all persons authorized to own or operate nuclear power plants under 10 CFR 50.

The general license is limited by several conditions, however. First, the license is

\footnotetext{
${ }^{10}$ Because approval of a TSAR is not a formal licensing action, there is no opportunity for public hearing or intervention (DOE 1989, I-22).

"Site-specific licensing is expected to fall off considerably as utilities augment on-site storage through general licenses (Roberts 2; Sturz 4).
} 


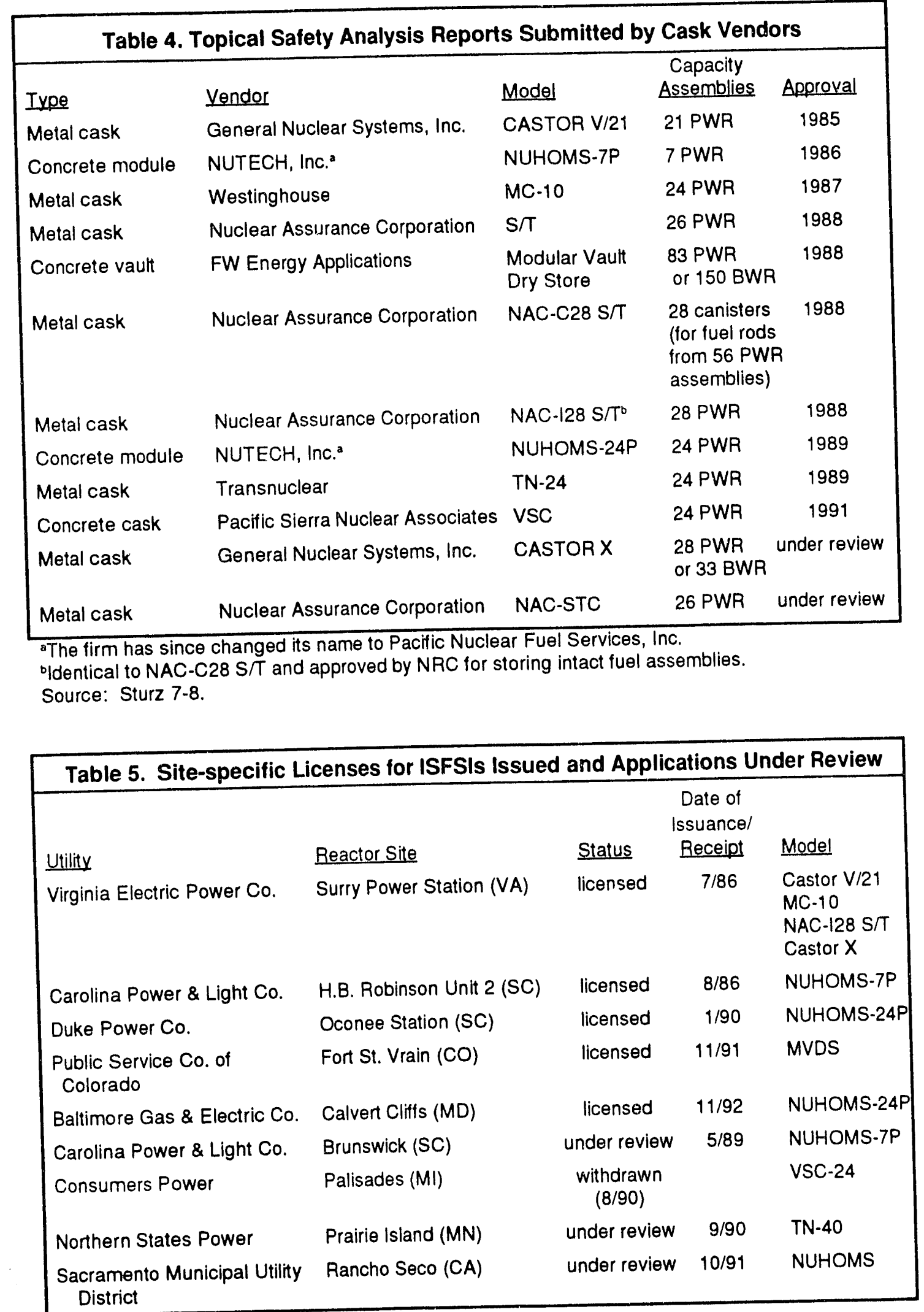

Source: Sturz 6. 
limited to the type of spent fuel the general licensee "is authorized to possess at the site under the specific license for the site." Second, spent fuel stored under the license can only be stored in casks certified by the NRC under Subpart L of 10 CFR 72. Lastly, the license expires 20 years after spent fuel is first stored in a certified cask. This period can be extended for another 20 years if the cask's certificate of compliance is renewed. ${ }^{12}$

A utility choosing to follow the general licensing path still remains subject to a number of regulatory requirements. The safety requirements specified in Part 72 continue to apply, as do the fixed-site safeguards requirements contained in Part 73 (Haughney 1992, 15). The utility must provide 90 -days notice before storing spent fuel in certified casks and must register the use of the cask no later than $\mathbf{3 0}$ days after first using it. Furthermore, the utility must conduct a review of the SAR submitted by the vendor (under Subpart $L$ ) to determine whether the parameters at the reactor site are enveloped by the cask design bases presented in the report. The utility also must determine whether the activities related to storage involve any unreviewed safety questions. A review of the plant's emergency plan and programs for quality assurance, training, and radiation protection must be conducted to see if operation of the ISFSI will reduce their effectiveness. In the event effectiveness is compromised, the utility must make appropriate changes to the plans and receive approval for the modifications. Lastly, the utility must allow the NRC access to its records and casks for inspection (\$72.212[b]).

A vendor may not begin fabricating casks until a certificate of compliance for the design has been issued. ${ }^{13}$ To have a cask certified for use under a general license, the vendor must submit an application to the NRC along with an SAR. Casks designed to store and transport spent fuel must be certified under 10 CFR Parts 71 and $72 .{ }^{14}$ As part of the application process, the NRC must be allowed to inspect the premises and facilities where casks have been or will be tested and fabricated. In addition, vendors must meet specific criteria for the design, fabrication, testing, and maintenance of casks (72.234).

In its final rule on general licenses, the NRC listed four cask designs that had received certificates of compliance (Table 6). The expiration date for all four casks is August 17, 2010. Four more applications for certificates were received in 1991. The NRC recently issued a final rulemaking approving one of the casks, and another cask is currently the subject of a proposed rulemaking (Sturz 9; Haughney 1992, 29-30; NRC 1992; NRC 1993). As of mid-April 1993, none of the approved casks is being used under the NRC's provisions for general licenses; however, the Consumers Power Company plans to follow the general license route for adding dry storage capacity at its Palisades plant in Michigan (for further information, see the section on Midwestern reactors).

${ }^{12}$ Cask vendors can apply for renewal of certificates of compliance. If they chouse not to du so, however, a cask user (or a representative of the user) can apply for cask design reapproval. If a certificate expires, "casks of that design must be removed from service after a storage period not to exceed 20 years" (\$72.212).

${ }^{13}$ In special circumstances, vendors may request exemption from this requirement under 10 CFR 72.7 (see, for example, the discussion of the Palisades ISFSI in the section on Midwestern reactors).

${ }^{14} 10$ CFR Part 71, "Packaging and Transportation of Radioactive Materials," applies to shipping casks. 
Table 6. Certificates of Compliance for Dry Spent-Fuel Storage Casks and Applications Under Review

\begin{tabular}{|c|c|c|c|c|}
\hline Type & Vendor & $\begin{array}{l}\text { Certificate/ } \\
\text { Docket \# }\end{array}$ & Model & $\begin{array}{l}\text { Capacity } \\
\text { (assemblies) }\end{array}$ \\
\hline Metal cask & General Nuclear Systems, Inc. & 1000 & CASTOR V/21 & 21 PWR \\
\hline Metal cask & Westinghouse & 1001 & $M C-10$ & 24 PWR \\
\hline Metal cask & Nuclear Assurance Corp. & 1002 & NAC $S / T^{a}$ & 26 PWR \\
\hline Metal cask & Nuclear Assurance Corp. & 1003 & $\mathrm{NAC}-\mathrm{C} 28 \mathrm{~S} / \mathrm{T}^{\mathrm{a}}$ & $\begin{array}{l}28 \text { canisters } \\
\text { (fuel rods } \\
\text { from } 56 \\
\text { PWR } \\
\text { assemblies) }\end{array}$ \\
\hline Concrete cask & Pacific Sierra Nuclear Assoc. & 1007 & VSC-24 & 24 PWR \\
\hline $\begin{array}{l}\text { Concrete } \\
\text { module }\end{array}$ & $\begin{array}{l}\text { Pacific Nuclear Fuel } \\
\text { Services, Inc. }\end{array}$ & $72-1004$ & $\begin{array}{l}\text { Standard NUHOM } \\
\text { NUHOMS-24P } \\
\text { NUHOMS-52B }\end{array}$ & $\begin{array}{l}\text { S } \\
24 \text { PWR } \\
52 \text { BWR }\end{array}$ \\
\hline Metal cask & Transnuclear & $72-1005$ & $\mathrm{TN}-24^{\circ}$ & 24 PWR \\
\hline Concrete cask & B\&W Fuel Company & $72-1006$ & CONSTAR & \\
\hline
\end{tabular}

aDual-purpose cask

-The NRC has proposed adding the cask to the list of approved storage casks (NRC 1992).

Source: 10 CFR 72.214; Sturz 9; Haughney 1992, 29-30.

\section{STORAGE TECHNOLOGIES}

\section{Decision Considerations}

Utilities seeking to expand their on-site spent-fuel storage capacity have several options available. Wet storage methods rely on water as the medium for cooling and shielding, and focus on increasing the capacity of spent-fuel storage pools located at reactor sites. In contrast, dry storage technologies rely on natural conduction, convection, and radiative heat transfer to cool spent fuel. Materials such as concrete, lead, and stainless steel provide shielding and radiation containment for the fuel (Resnik off 318).

Although spent-fuel storage is safe and involves relatively simple technology, there are certain risks that utilities weigh in selecting a storage technology. A primary concern is the technical risk associated with the method of storage. Factors to consider include the complexity and reliability of the technology, as well as whether or not its performance has been demonstrated at other sites. Cost considerations include how fully defined the costs are and the estimated cost of purchasing additional storage units (Lambert 3). Obtaining a license for the new storage capacity entails its own set of risks. For example, licensing actions that are subject to public intervention or those involving as yet unlicensed technologies could require a significant amount of time to complete (Lambert 4).

Storage technologies that involve major construction may add to the risks associated with scheduling, especially if construction is susceptible to delay. Perhaps the most important risk, however, is the effect the storage technology may have on utility operations. Fuel 
storage may create scheduling conflicts with normal utility operations or it may expose workers to high-than-anticipated levels of exposure (Lambert 4). An additional factor to consider is how the local community is likely to react to the chosen technology (Lambert 8).

\section{Wet Storage Concepts}

Reracking. Storage racks have been used in spent-fuel pools since 1959. Made of aluminum or stainless steel, storage racks are designed to prevent criticality in pools by maintaining adequate spacing between assemblies (NEA 33-34). With the need for greater storage space, utilities began reracking their pools to reduce the spacing between assemblies from 20 to about 12 inches (Carter 17). Even closer spacing can be achieved by using racks containing neutron-absorbing materials (e.g., boron carbide), using racks that depend on water and stainless steel flux traps, or imposing higher burnup requirements (DOE 1989a, I19). Depending on the facility, reracking has the potential to increase in-pool storage capacity by 40 to $($ ver 100 percent for intact fuel assemblies (Johnson 1031).

Reracking affects other factors besides criticality. Pools must be structurally capable of supporting the weight of the additional spent fuel. Furthermore, reracked pools must meet the NRC's site-specific seismic criteria. Heat generation, pool cooling, shielding from radiation, water clean-up, and the ability to accommodate in-service inspections are other factors to consider (DOE 1989a, I-19).

Utilities have generally turned to reracking as their first option for increasing atreactor storage capacity. One reason for this choice is that reracking is based on proven technology supported by a well-developed industry of vendors and technical consultants. In addition, reracking is usually the least costly option available (DOE 1989a, I-19; Johnson 1031). Costs will vary depending on the individual situation, particularly on the original storage capacity. A reasonable estimate of the costs of reracking ranges from $\$ 10,000$ to $\$ 16,000$ per PWR assembly of space gained, assuming a discount rate of 5 percent (Johnson 1031).

Before reracking their storage porols, utilities must first obtain a license amendment from the NRC allowing an increase in the amount of spent fuel stored in pools. All formal licensing actions involve both an opportunity for public hearing and possible intervention through litigation. As a consequence, many utilities have experienced delays in obtaining amendments to their operating licenses. In October 1985, Pacific Gas and Electric (PG\&E) applied for a license amendment to rerack the Diablo Canyon spent-fuel storage pools and thereby increase the capacity of each pool from 270 to 1,324 assemblies (GAO 1, 6). Three local groups intervened in the licensing proceedings in February 1986 and asked the NRC to hold hearings on the proposed reracking. Prior to conducting the hearings, however, the NRC issued the license amendment (GAO 1). ${ }^{15}$ The interveners then challenged the NRC's decision in federal court.

After the NRC issued the license amendment, PG\&E installed high-density racks in its as yet empty, uncontaminated pools. By court order, however the utility was prohibited from using the racks until the NRC held a hearing. When the Diablo Canyon Unit 1 reactor needed to be refueled, PG\&E was faced with either shutting down the reactor or reinstalling the original racks, filling the pool, and placing the discharged fuel in storage (GAO 7). PG\&E chose the latter option. As a consequence, when reracking resumed in November 1987, the

${ }^{15}$ Under 10 CFR 50.90, the NRC may issue a license amendment before conducting a hearing, provided it has made a finding of no significant hazard. 
procedure was much more complicated than before, requiring the handling and removal of spent fuel (GAO 8).

Despite such litigation-related delays in granting license amendments, the NRC has issued a large number of amendments for reracking. In fact, in the U.S., reracking has taken place in nearly all the storage pools that are structurally capable of supporting the additional weight (DOE 1989a, l-19). Some utilities have reracked their pools more than once (Johnson 1031).

Rod consolidation. Like reracking, rod consolidation uses existing storage space more efficiently by increasing the density of fuel rods per unit of area. When used in conjunction with reracking, rod consolidation can increase the capacity of existing pools from 1 and $-1 / 3$ to 10 reactor cores (Resnikoff 321 ). While the actual procedure takes place under water, it should be noted that rod consolidation can also be used to maximize the efficiency of dry-storage methods.

Rod consolidation reduces the volume of waste by removing fuel rods from assemblies and placing them in more compact arrays inside canisters. Because fuel rods in intact assemblies are spaced so as to maximize the potential for criticality, placing the rods into tighter arrays actually reduces the possibility of criticality occurring in the spent-fuel pool. The closer spacing makes it possible to house the fuel rods from two assemblies in one canister that takes up the same area as one intact assembly. The non-fuel-bearing hardware (e.g., end fittings, grid spacers) is compacted and placed in a separate canister.

Consolidation can be described in terms of three ratios: rod consolidation (the number of fuel assemblies per canister of fuel rods), hardware compaction, and total consolidation, which combines the first two. Under certain circumstances, a rod consolidation ratio of $2: 1$ can be achieved. The hard ware-compaction ratio ranges from $6: 1$ to 10:1 (Johnson 1032). Ten assemblies can thus be consolidated into 6 to 6 -and-2/3 storage slots (5 canisters for fuel rods plus 1 to 1 -and-2/3 canisters for non-fuel-bearing hardware). This reduction in volume amounts to an increase in storage capacity of between 50 and 70 percent, with some industry experts confident that this factor can increase to 100 percent with the use of more sophisticated equipment (Johnson 1(132).

As with reracking, rod consolidation can only be performed in pools capable of both supporting the weight of the additional fuel and meeting the NRC's seismic criteria. Another factor to consider is the difficulty of the process from an operations perspective. Extracting the rods from the assemblies, loading them into canisters and compacting the non-fuel bearing hardware can take two workers 30 hours each per assembly (Resnikuff 321). In addition to the cost of such an operation, the increased handling of fuel is also likely to increase the exposure of workers to radiation (Johnson 1032; Resnikoff 321).

While reracking is considered proven technology, rod consolidation is still in the advanced demonstration stage. Six demonstrations have been conducted, most of them in cooperation with DOE (DOE 1989a, I-66). Rod consolidation ratios of 2:1 have been achieved; there has been little success, however, in compacting non-fuel-bearing hardware (Table 7) (DOE 1989a, I-66). Two of the utilities participating in these demonstrations have received licenses to store consolidated spent fuel - the Rochester Gas and Electric Company for its Ginna reactor pool and the Northeast Utilities Company for the Millstone Unit 2 storage pool (DOE 1989a, I-67). Large-scale, long-term storage of consolidated fuel has not to date been demonstrated for either wet or dry technologies. The Oconee demonstration marks the longest running period of extended storage. The four PWR assemblies consoli- 


\begin{tabular}{|c|c|c|c|c|}
\hline Date & Participants & Sile & $\begin{array}{c}\text { Rod } \\
\text { Consol. } \\
\text { Batio }\end{array}$ & $\begin{array}{c}\text { Hardware } \\
\text { Consol. } \\
\text { Batio }\end{array}$ \\
\hline 1982 & Duke/Westinghouse & Oconee (SC) & $2: 1$ & $6: 1$ \\
\hline 1983 & Maine Yankee/Proto-power & Maine Yankee (ME) & $1.6: 1$ & NA \\
\hline $1985-86$ & $\begin{array}{l}\text { Rochester Gas and Electric } \\
\text { Nuclear Assurance }\end{array}$ & West Valley (NY) & $1.8: 1$ & NA \\
\hline 1986 & $\begin{array}{l}\text { Rochester Gas \& Electric } \\
\text { U.S. Tool \& Die }\end{array}$ & Battelle $(\mathrm{OH})$ & $1.8-2.0: 1$ & NA \\
\hline 1987 & $\begin{array}{l}\text { Northeast Utilities } \\
\text { Combustion Engineering }\end{array}$ & Millstone $2(\mathrm{CT})$ & $2: 1$ & NA \\
\hline 1987 & $\begin{array}{l}\text { Northern States Power } \\
\text { Westinghouse }\end{array}$ & Prairie Island (MN) & $2: 1$ & NA \\
\hline
\end{tabular}

aEvery demonstration worked with PWR fuel.

'All assemblies were from the R.E. Ginna PWR reactor, including some defective rods.

Source: DOE 1989, 1.66 - 1.68.

dated in that demonstration have been in wet storage for 10 years. DOE does not anticipate any problems with longer periods of storage (DOE 1989a, I-68).

The lack of large-scale demonstrations, particularly regarding compaction of nonfuel-bearing hardware, makes estimating the costs of rod consolidation difficult. The total cost of at-reactor consolidation is made up of several components: the cost of equipment (including installation) and canisters, operating costs, ${ }^{10}$ and the costs of complying with NRC requirements (DOE 1989a, 1-69). The cost of canisters varies because canisters will be sized to fit the existing storage racks. In addition, the cost per canister depends on the type of fuel, with the smaller BWR canisters being less expensive.

DOE calculated the total fixed costs to range from $\$ 1.7$ million to $\$ 3$ million, which includes $\$ 200,000$ to $\$ 500,000$ for licensing. Variable costs are estimated to range from $\$ y$ to $\$ 14$ for every kilogram of heavy metal consolidated. ${ }^{17}$ The latter figure corresponds to a cost of between $\$ 25$ and $\$ 43$ for every kilogram of heavy metal gained in terms of storage space (DOE 1989a, I-71).$^{18}$ These estimates are based on the assumption that the same type of canister will be used for both fuel rods and non-fuel-bearing hardware. ${ }^{10}$

16Estimates of operating costs depend upon the type of fuel being consolidated. P'er kilogram
of heavy metal, operating costs for BWR fuel are slightly higher than for PWR fuel (DOE 1989, 1-70).

${ }^{17}$ Unless otherwise noted, cost estimates are for a weighted average of PWR and BWR fuel. Dollar figures have not been adjusted for inflation. For more information on cost estimates, see Appendix 5.

${ }^{18}$ Assuming the total consolidation ratio to be $10: 6$, consolidating 10 assemblies of spent fuel will result in a gain of 4 storage spaces. Therefore, to gain one unit of additional storage space, 2.5 assemblies must be consolidated. DOE bases its cost estimates on weighted averages of 2.6 and 3.0 assemblies per unit gained for the low-and high-cost estimates, respectively (DOE 1989, I-71).

${ }^{10} \mathrm{The}$ low-cost estimates assume a weighted total consolidation ratio of 1.63 , whereas the high-cost estimates are based on a lower ratio of 1.5 (DOE 1989, l-70). 
Using these numbers, DOE calculated that the costs of storing consolidated assemblies range from $\$ 40$ to $\$ 75$ for expansions of 100 metric tons of heavy metal (MTHM) and $\$ 30$ to $\$ 50$ for expansions of 300 MTHM (see Table 8, p. 24) (DOE 1989a, 1-86)..$^{20}$ An independent report estimated the costs per PWR assembly to range from $\$ 5,000$ to $\$ 9,000$ per assembly or $\$ 13,000$ to $\$ 23,000$ per assembly of added storage capacity (Johnson 1032).

As with reracking, a utility must obtain an amendment to its operating license before storing consolidated fuel. As part of the process, a safety analysis report covering a variety of factors (e.g., potential for criticality, structural integrity of the pool and racks, seismic design) must be submitted and approved by the NRC. Additional licensing issues involve safeguarding nuclear material - specifically, identifying the means for establishing the amount of fuel stored in each container and verifying on a regular basis that the fuel remains in the container (DOE 1989a, I-68, l-69).

Licensing delays may create difficulties for utilities that plan to relieve their spentfuel storage problems through rod consolidation. Intervention by an anti-nuclear group and later by the state of Maine led the Maine Yankee Power Company to withdraw its application for a licensing amendment to store consolidated fuel. Rochester Gas and Electric Company, however, received a license amendment in 1985 to store consolidated fuel in its Ginna reactor pool. Similarly, Northeast Utilities Service Company received an amendment in 1988 that permitted it to store consolidated fuel in 688 locations in the reactor pool of Millstone Unit 2 (DOE 1989a, l-69).

New pool construction. Although constructing a new storage pool offers an advantage in that the technology is proven and has been successfully licensed over the past 30 years, this alternative requires a significant initial outlay of capital and is thus less flexible to changes in storage requirements (Johnson 1032-3). According to one report, a new pool with a capacity of 500 MTU may cost from $\$ 40$ to $\$ 80$ million to build and generate annual operating costs on the order of $\$ 1.5$ million. With a useful lifetime of 20 years, and assuming $25 \mathrm{MTU}$ of spent fuel are loaded each year, the costs per assembly can range from $\$ 90,000$ to $\$ 180,000$. The cost would increase significantly if the total amount of fuel placed in storage turned out to be less than the design capacity (Johnson 1(1)33).

\section{Dry Storage Concepts}

Dry storage technologies have been in use in the United Kingdom since 1972 (NEA 24). In the United States, demonstration projects have been underway since 1982. As discussed earlier, dry storage technologies employ natural conduction, convection, and radiative heat transfer for cooling spent fuel. Materials such as concrete, lead, and stainless steel provide the shielding and radiation containment necessary for safe storage (Resnikoff 318). A report by the OECD's Nuclear Energy Agency identified several advantages of dry storage methods over the proven technology of pool storage as a long-term storage option. Specifically, the report found dry storage in an inert gas atmosphere to be better than pool storage at preserving fuel and cladding in a pristine condition. Dry storage also produces less active waste, incurs lower operating and maintenance costs, and is better able to withstand hazards such as seismic events and loss of cooling (NEA 34-35). In addition to these advantages, utilities find dry storage methods attractive because their modular designs do not necessarily require huge initial outlays of capital (DOE 1989a, I-41).

Appendix 5.

${ }^{20}$ For a summary of DOE's cost estimates for the various methods of interim storage, see 
Because gases are less capable of transferring heat than water, spent fuel stored in a dry condition will be at a higher temperature than it would be if stored in water. The oxidation rates of spent fuel and its cladding are temperature dependent; therefore, in storing fuel with high decay rates, the main hazard associated with dry storage is the exposure of the fuel assemblies to air. To protect against oxidation, dry storage systems often surround the spent fuel with a purified inert gas such as helium or argon (NEA 35).

Modular concrete vaults. Although the use of vaults to store spent fuel is well established in the United Kingdom, this method of dry storage has not been tested as extensively in the United States (NEA 36). One reason for the slow growth of this method is that, until relatively recently, vault storage was not a modular system. The large upfront investment of capital required to construct such a facility, plus the long period of time needed to recoup that investment, led many utilities to opt for a more flexible storage method. Recent developments in vault technology, however, now make this dry method more economically feasible (Johnson 1033).

Spent fucl stored in vaults is sealed in carbon steel tubes that are housed in a massive concrete structure (Figure 3) (NEA 36). The atmosphere inside the tubes can consist of air or a cover gas such as nitrogen (DOE 1989a, I-60). Each tube ca' 1 hold a single assem-

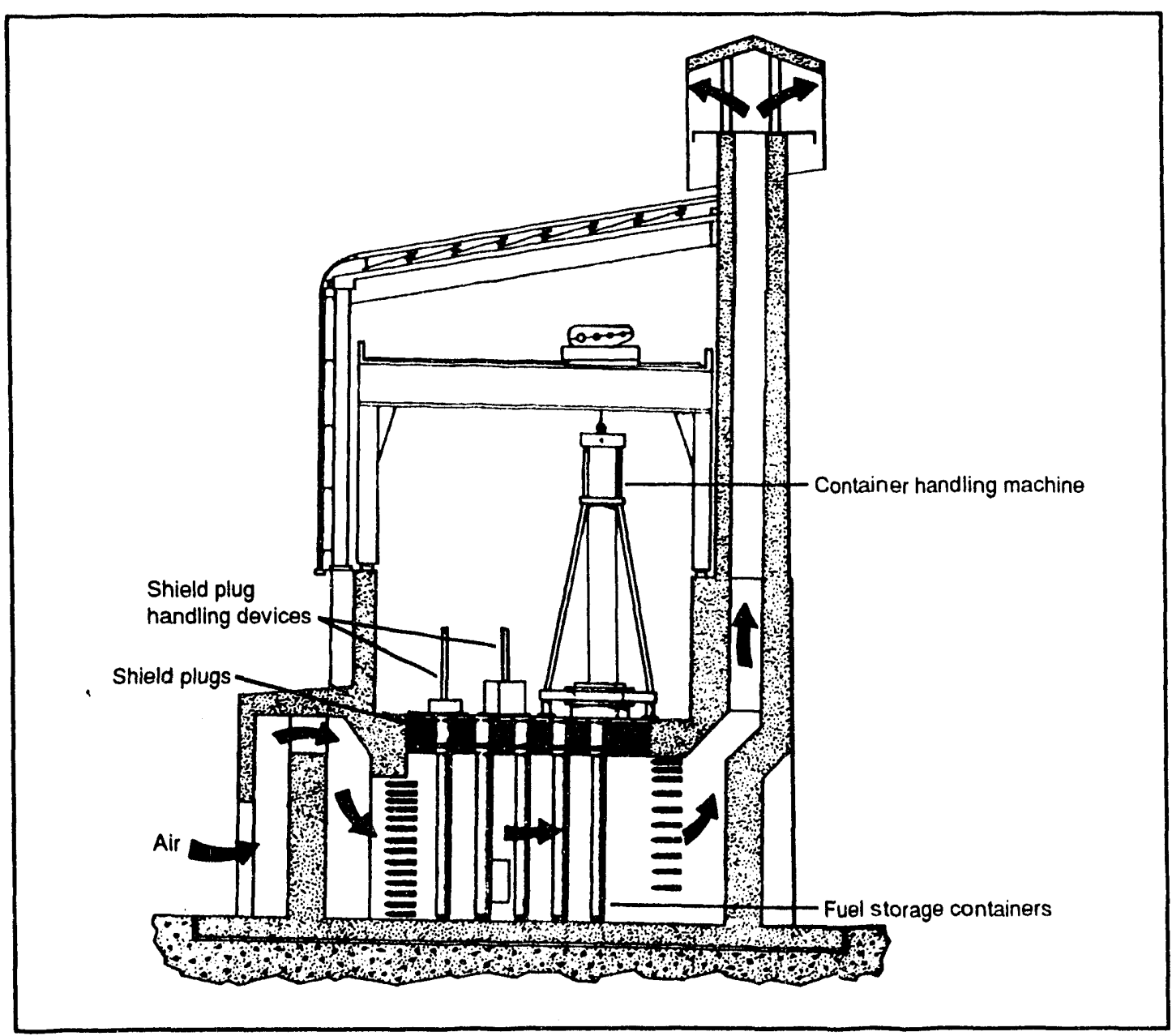

Figure 3. Modular Vault Dry Storage Facillity at Fort St. Vrain

Source: Holt. 
bly of unconsolidated fuel and is accessible from the floor of the fuel-handling bay via a removable shield plug. Natural convection through a system of air ducts and cooling channels removes heat from the fuel-storage tubes (DOE 1989a, 1-61). Inlets near the bottom of the structure allow air to flow in and enter the space between the tubes. The heat given off by the spent fuel warms the air, causing it to flow upward and exit the facility through outlet ducts at the top.

In addition to the modular storage units, an ISFSI employing vault technology consists of a cask-handling area and a fuel-handling machine capable of providing shielding while transferring fuel from the transport casks to storage tubes (DOE 1989a, I-61). Fuel loading operations start with the transfer of spent fuel from the reactor poll to a standard transport cask. Once the loaded cask is inside the cask-handling area, the cask lid is removed and the cask is positioned under the fuel-handling machine stationed in the loading port in the fuel-handling bay above (DOE 1989a, I-62). A shielding skirt covers the interface between the cask and the fuel-handling machine. The fuel-handling machine then removes the shield plug from the loading port, hoists the spent-fuel assembly into its fuel cavity, and reinstalls the shield plug in the loading port. With the fuel assembly temporarily housed inside the cavity, the fuel-handling machine moves to the desired fuel tube. After docking, the machine removes the shield plug on the fuel tube, lowers the fuel assembly into the tube, and reinstalls the plug (DOE 1989a, I-62, I-63). The fuel tube is then evacuated and filled with the cover gas. Reversing this sequence of events makes it possible to remove fuel from dry storage for transporting (DOE 1989a, I-63).

One report cited vendor-supplied cost estimates of $\$ 29$ million to construct a vault with a capacity of $500 \mathrm{MTU}$ and $\$ 250,000$ per year to operate the facility. Based on these estimates, and on $25 \mathrm{MTU}$ of spent fuel loaded annually over a useful life of 20 years, the unit costs of storage amount to about $\$ 50,000$ per assembly. This figure can be considered the lower bound of costs, since utilities in the United States have very limited experience in licensing, constructing, and operating ISFSIs based on modular vault storage. A reasonable upper range would be 50 percent greater, or $\$ 75,000$ per assembly (Johnson 1033). DOE estimated the lower range of storage costs based on 10 years of storage to be $\$ 110$ per kilogram of heavy metal for an installation with a capacity of $100 \mathrm{MTHM}, \$ 55$ for 500$)$ MTHM, and $\$ 50$ for 1,000 MTHM (see Table 8). The upper bound would likewise be 50 percent higher (DOE 1989a, l-64).

In 1988, the NRC approved a topical report submitted by Foster-Wheeler Energy Corporation (the U.S. licensee of GEC-Alsthom in the United Kingdom) for its modular vault dry store (MVDS) system (Holt 1-2). The following year, the Public Service Company of Colorado (PSCo) selected the MVDS system for use in an on-site ISFSI at its Fort St. Vrain reactor. ${ }^{21}$ On February 1, 1991, the NRC issued an environmental assessment and finding of no significant impact for the site. Construction of the facility began shortly thereafter and ended in September 1991. Completely separate from the reactor building, Fort St. Vrain's ISFSI contains six storage vaults at ground level, each 20 feet tall. Together, the six vaults hold up to 270 containers of fuel, sufficient space to store 1,488 spent-fuel blocks from the Fort St. Vrain reactor (Holt 2 ).

The containers in each of the Fort St. Vrain vaults are arrayed in a honeycomb fashion to maintain subcriticality and to maximize cooling (Holt 3 ). The vaults are passively cooled, with outside air entering the facility at ground level on the east side, travelling

${ }^{21}$ Fort St. Vrain is a high-temperature gas-cooled reactor, however the MVDS system is not limited to this type of fuel (Holt 3 ). 
through the cooling channels, and exiting the building on the west side via an 80-foot chimney. The facility itself, with walls of 3 - to 4 -foot thick steel-reinforced concrete, is capable of withstanding winds up to $360 \mathrm{mph}$, floodwaters up to 6 feet deep, and earthquakes of a magnitude greater than any recorded in Colorado (WIEB Section 5 ). The facility is licensed for a 20-year period, however a planned extension of that license will permit spent-fuel storage for up to 40 years (Holt 2).

Horizontal concrete modules. Storage systems utilizing horizontal concrete modules consist of several elements. The spent fuel is stored in metal baskets inside stainless-steel canisters filled with helium or nitrogen. The baskets maintain the spacing of the fuel to control criticality. The canisters are housed within the concrete module itself, which provides physical protection and shielding. The modules generally form two rows (Figure 4). Radiation, conduction, and natural convection all work to remove the heat generated by the spent fuel. The storage facility includes a central monitoring and security system. Typically, 50 to 450 square feet of space are required for every MTHM stored, depending on the capacity of each module (DOE 1989a, 1-57).

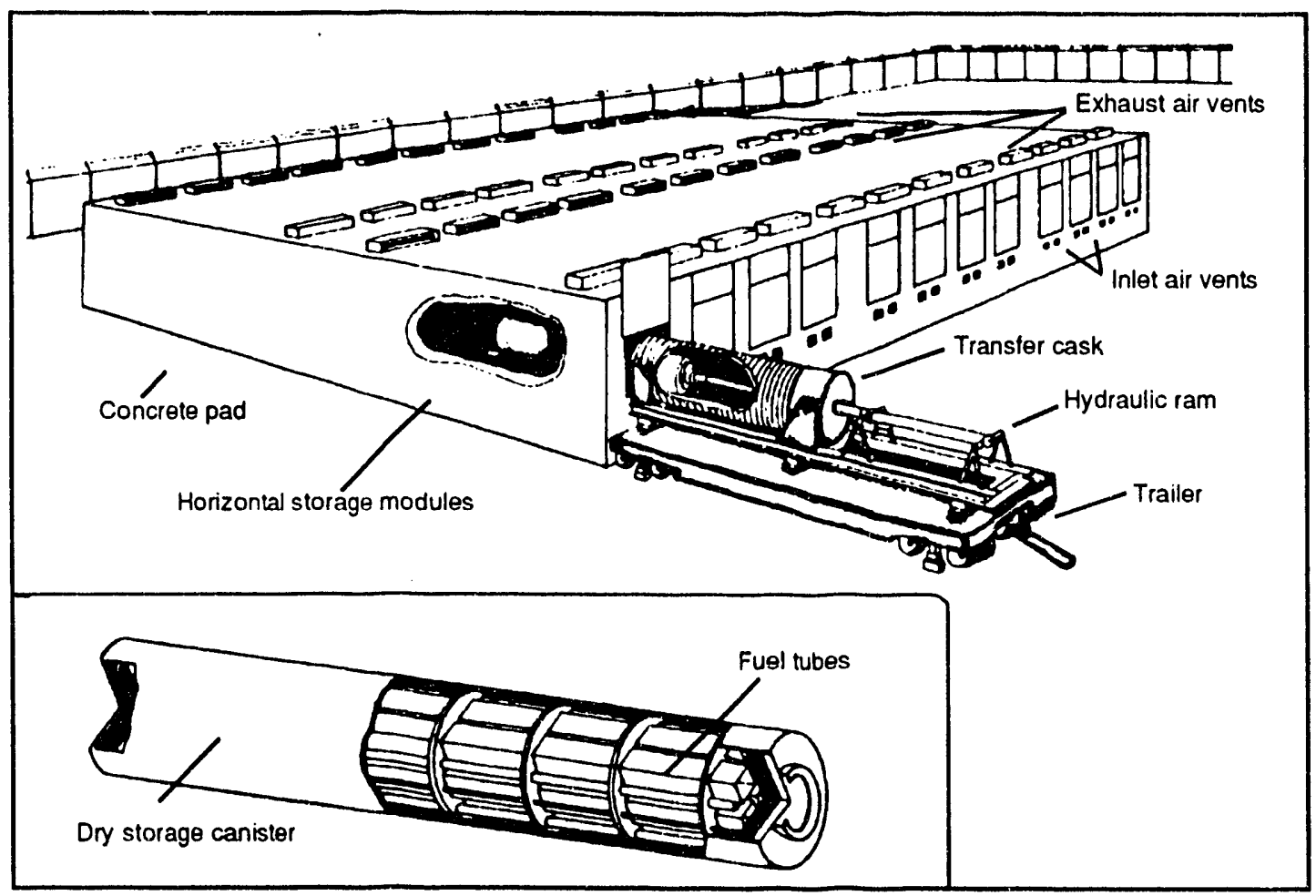

Figure 4. Generic Horizontal Modular Storage System (NUHOMS) Source: DOE 1989a, Figure 4-4.

The storage canister is placed into a transfer cask and the entire package (canister and transfer cask) is lowered into the spent-fuel pool. Assemblies are loaded into the storage canisters while in the spent-fuel storage pool. Following fuel-assembly loading, the transfer cask lid is installed and the transfer cask is removed from the spent-fuel pool. The canister shield plug is welded to the canister and the canister and cask are vacuum dried. The canister is then filled with helium to protect the fuel from oxidation during storage. The transfer cask is transported to the dry-storage facility on a special trailer. 
Emplacement of the fuel inside the storage module involves removing the lid of the transfer cask, aligning the cask with the docking port of the module, and pushing the canister into the module with a hydraulic ram. Finally, the module is sealed by welding a 2inch thick steel door to the docking port (DOE 1989a, 1-58).

Based on experience in the United States, DOE estimated the costs of licensing an ISFSI using horizontal concrete modules to range from $\$ 300,000$ to $\$ 1$ million. The unit costs for such a facility ranged from $\$ 60$ to $\$ 80$ per kilogram of heavy metal for a capacity of 100 MTHM, to $\$ 40$ to $\$ 55$ for a capacity of 1,000 MTHM (see Table 8). These cost estimates include not only the costs associated with licensing, but also the purchase of a transfer cask, hydraulic ram, and cask transporter, and the costs of a monitoring and security system (DOE 1989a, 1-60). A separate study estimated the costs to range from $\$ 15,000$ to $\$ 25,000$ per PWR assembly stored (Johnson 1034).

The NUTECH Horizontal Modular Storage (NUHOMS) system is capable of holding 7 PWR assemblies of spent fuel that has cooled for 5 years or 24 PWR assemblies cooled for 10 years. The system consists of a dry shielded canister, a reinforced concrete horizontal storage module, and a transfer cask to use in loading the module. The module itself protects the dry shielded canister from natural phenomena and provides both radiation shielding and a means of removing heat (McConaghy et al. 380). The NUHOMS-07P system uses a fuel basket that contains neutron absorbers, whereas baskets for the NUHOMS-24P system do not contain such materials (McConaghy et al. 382).

The NUHOMS system has been licensed for use in ISFSIs at three nuclear power plants in the United States. The Carolina Power and Light Company (CP\&L) chose the NUHOMS-07P system for use at its H.B. Robinson facility near Hartsville, South Carolina. The installation consists of eight modules (with a total capacity of 56 assemblies) and is licensed for 20 years. Construction commenced in 1987 as part of a demonstration program sponsored jointly by CP\&L, DOE, NUTECH ${ }^{22}$ and the Electric Power Research Institute (EPRI). The system designed for this site differs from the generic design in that the modules are arranged in a single row and a hydraulic ram pulls rather than pushes the canister into the storage modules (DOE 1989a, 1-58).

The Duke Power Company selected the NUHOMS-24P system for an ISFSI at its Oconee station near Seneca, South Carolina. The total capacity of this installation is 88 modules, which makes the system capable of meeting storage needs over the useful life of the Cconee plant (McConaghy et al. 384). The facility was licensed in January 1990, and fuel loading operations began in July of that year (McConaghy et al. 380). Over a period of 6 days, 24 PWR assemblies were loaded into one dry shielded canister. The bulk of the time was spent welding and loading, handling, and decontaminating the canister (McConaghy et al. 385-6). By the end of 1990, four 24P canisters had been loaded (McConaghy et al. 380).

In November 1992, Baltimore Gas and Electric received a license to store spent fuel in an ISFSI at the Calvert Cliffs plant also using the NUHOMS-24P system (DOE 1993b, 28). License applications for ISFSIs using the NUHOMS systems are pending for the Brunswick (North Carolina) and Rancho Seco (Califomia) nuclear plants (Haughney 1992, 13). In addition, Pacific Nuclear Fuel Services has submitted applications to certify its NUHOMS technology under the NRC's general license provisions (Haughney 1992, 30).

Metal casks. In the United States, storing spent fuel in metal casks is "in the initial

${ }^{22}$ NUTECH has since changed its name to Pacific Nuclear Fuel Services, Inc. (Sturz 7). 
stages of production usage, and reasonably well demonstrated" (Johnson 1033). A typical metal cask is cylindrical, approximately 16 feet long and 8 feet in diameter, and weighs $1(0)$ to 125 tons when loaded with spent fuel. The storage pad area necessary to accommodate metal casks in a vertical orientation is typically 25 square feet per MTHM stored. A horizontal orientation would require a much larger space for the same volume of fuel (DOE 1989a, 1-44).

Metal casks contain fuel baskets capable of holding 21 to 32 PWR ( 52 to 76 BWR) spent-fuel assemblies, if intact, or an equivalent number of canisters of consolidated fuel (Figure 5) (Johnson 1033). The fuel baskets generally are made of borated stainless-steel or some combination of stainless steel, copper, aluminum, and boron (DOE 1989a, l-43). The configuration of fuel assemblies inside the cask is based on the assumption that the fuel is equivalent to fresh fuel - that is, the reactivity of the fuel is considered to be so high that minimizing the spacing between assemblies is not an option. Current research is focusing on ways to verify the burnup of spent fuel to permit utilities to take credit for fuel burnup and thereby increase the density of the spacing (DOE 1989a, 1-43).

The body of the cask is usually fabricated of forged steel, nodular cast iron, or lead and stainless steel. The thickness of the cask walls is sufficient to provide shielding from gamma radiation, and the entire cask is encased in neutron-absorbing materials. The external surface of the cask is often "finned" to enhance cooling capacity (DOE 1989a, 1-43).

Metal casks can be loaded through either a wet or dry procedure. The more common method is wet loading, which takes place in the pool and is approved by the NRC. By this method, remotely controlled equipment is used to load intact or consolidated spent fuel into the metal cask. When loading is complete, the lid is installed and the cask is removed
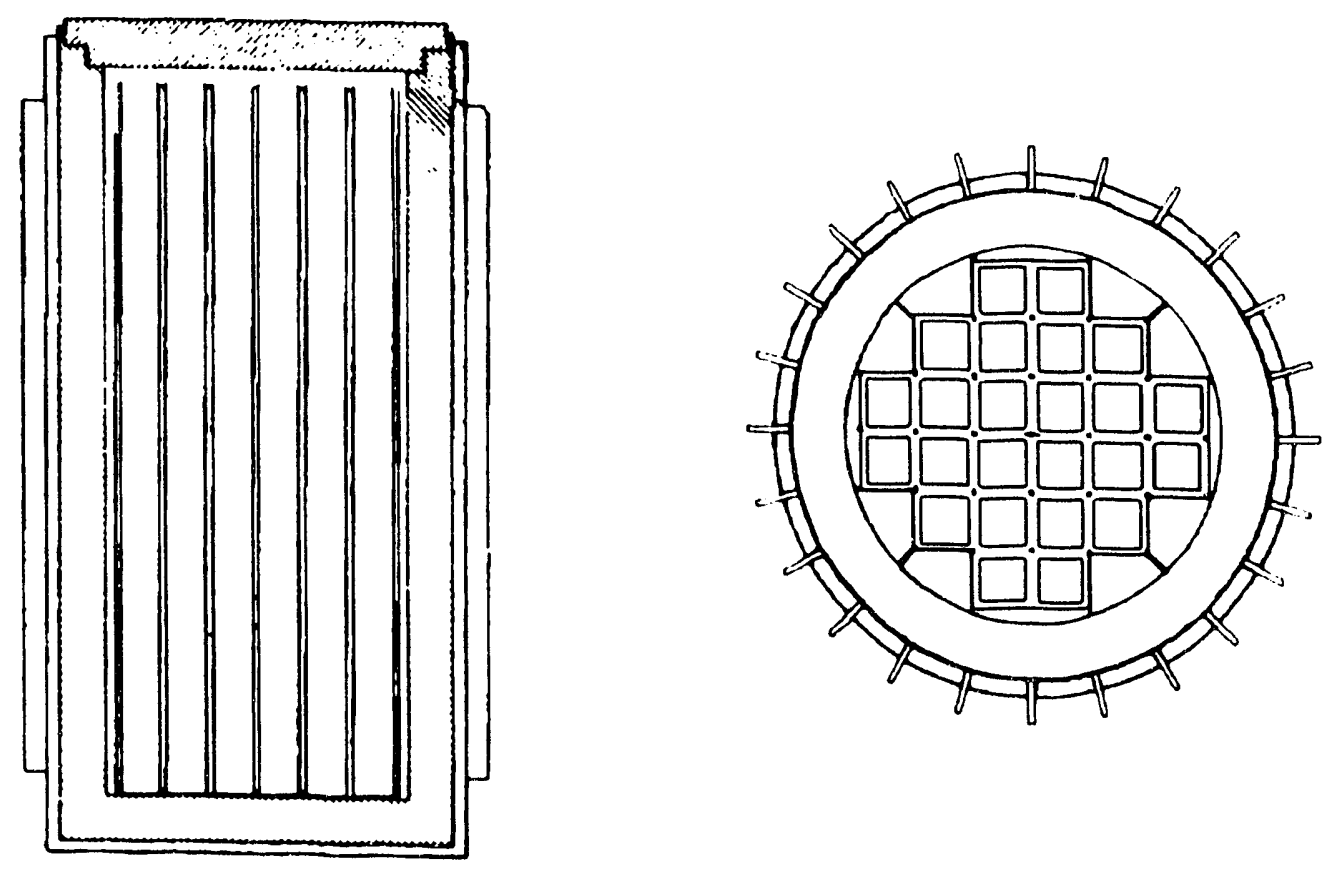

Figure 5. Conceptual Design for a Typical Metal Cask

Source: DOE 1989a, Figure 4-1. 
from the pool and drained. The next series of steps takes place on the decontamination pad. The lid is tightly secured, the cavity of the cask is vacuum-dried, and the cask is filled with a cover gas and checked for leaks. Finally, the exterior surfaces of the cask are washed to remove any radioactive parti les and the cask is transported to the dry storage facility (DOE 1989a, (-43).

Utilities that do not have access to a crane capable of lifting a fully loaded cask weighing 100 to 125 tons may be able to take advantage of the dry loading method (DOE 1989a, 1-44). Dry loading utilizes a transfer cask that is lighter than the metal cask but is handled in much the same way as described above for wet loading. At the dry-storage pad, the storage and transfer casks are connected with a fuel-transfer collar. ${ }^{23}$ Spent-fuel assemblies can then be lowered into the storage cask. ${ }^{24}$ When fully loaded, the storage cask is vacuum-dried and filled with a cover gas (DOE 1989a, 1-44).

Because metal cask storage is available commercially, there is less cost uncertainty associated with this mode of storage than with some of the other methods. Costs that must be considered include licensing, construction of the dry storage facility, the cost of the casks, and operating and monitoring costs. The greatest variable cost is that of the casks themselves. The unit cost per cask depends on the quantity purchased and on the level of competition between vendors and alternative storage technologies (DOE 1989a, 1-47).

Based on actual costs, DOE estimated the costs associated with licensing to range from $\$ 300,000$ tn $\$ 1$ million. The cost of constructing the storage facility range from $\$ 500,000$ to $\$ 1$ million. Among variable costs, cask costs were assumed to range from $\$ 50$ to $\$ 90$ per kiiogram of heavy inetal, while the costs of loading and placement were set at $\$ 1$ to $\$ 2$ per kilogram (DOE 1989a, I-47). DOE's estimate for the average unit cost range from $\$ 60$ to $\$ 115$ per kilogram for added capacity of 100 MTHM to a low estimate of $\$ 55$ to $\$ 100$ per kilogram to store 1,000 MTHM (see Table 8). In both cases, over 90 percent of the cost stems from purchasing the casks (DOE 1989a, I-48).

Between 1984 and 1988, four types of metal casks were tested under DOE cooperative agreements. In 1984, the Virginia Power Company, DOE, and EPRI collaborated in a test of three metal casks for storing PWR fuel: Castor V/21 (General Nuclear Systems, Inc.), TN-24P (Transnuclear), and MC-10 (Westinghouse Electric). Conducted at the ldaho National Engireering Laboratory (INEL), the tests demonstrated that all three casks could be safely handled and loaded and, with only minor modifications, could be used at reactor sites to store spent fuel (DOE 1989a, 1-45).

One of the casks - the TN-24P model - was later tested at INEL for storing 48 consolidated PWR assemblies. Although the neutron dose rates at the surface of the cask were higher than they had been in the test with intact fuel, minor adjustments of the neutron shielding could reduce these rates considerably. The test also showed gamma-dose rates to be lower than in the first demonstration because the canisters of consolidated fuel did not contain the assembly end fittings, which are the major sources of s'ich radiation (DOE 1989a, (-45).

In 1986, Virginia Power received a license to store 811 MTU of spent fuel in an ISFSI

\footnotetext{
${ }^{23}$ The NRC has not approved any method for dry loading spent-fuel assemblies into storage casks at the storage pad (Haughney 1993, 2).

${ }^{24}$ Depending on the mechanism for mating the two casks, the fuel assemblies may first have to be inserted into canisters (DOE 1989a, 1-44).
} 
at its Surry site in southeastem Virginia. By the end of 1992, Virginia Power had placed 168 MTU in dry storage at the site. The storage facility consists of 17 loaded casks: 15 Castor V/ 21 casks, one NAC-128 cask, and one MC-10 cask.

As mentioned previously, all four casks initially certified for use under the NRC's general licensing provisions were metal (see Table 6). In June 1992, the NRC proposed

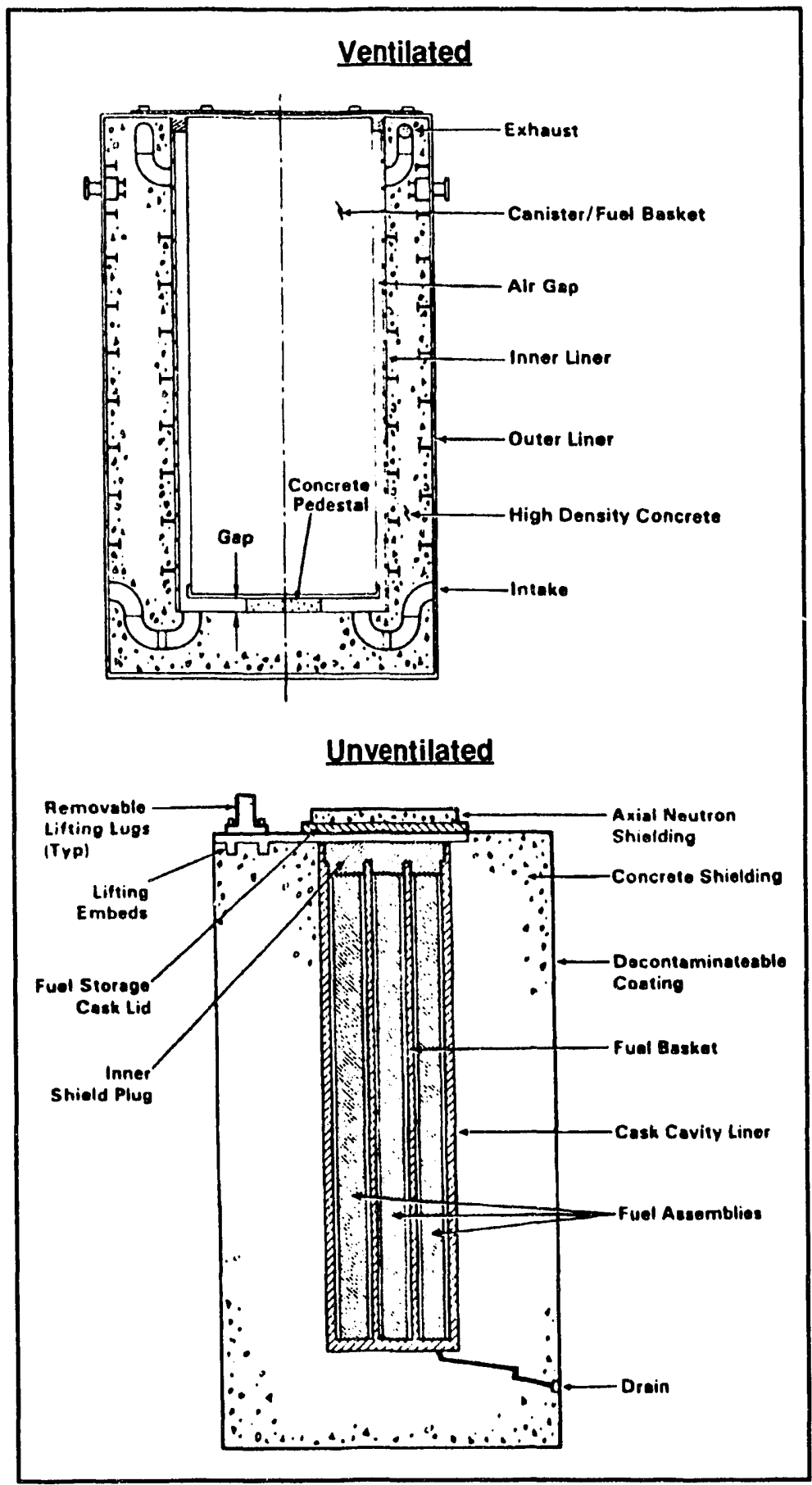

Figure 6. Conceptual Designs for Concrete Storage Casks Source: DOE 1989a, Figures 4-2 and 4-3. adding another metal cask - Transnuclear's TN-24 model - to the list of approved casks (NRC 1992b).

\section{Concrete} storage casks. Dry storage in concrete casks is similar in concept to storage in metal casks, and appears to be highly competitive in terms of economics. Concrete casks measure approximately 18 feet in length by 8.5 feet in diameter and weigh close to 90 tons when loaded (Figure 6). The main physical difference between a metal and a concrete cask is that the latter has a thick body made of reinforced concrete, which provides shielding from gamma radiation. Scientists have developed special kinds of concrete capable of withstanding temperatures of up to $230^{\circ} \mathrm{C}$, extreme fluctuations in temperatures, fires, and impacts from being dropped (DOE 1989a, I-52).

Concrete casks are sealed in one of two ways. A metal outer lid may be attached once concrete shield plugs have been inserted into the individual cells of the fuel basket. A second 
method of closing the cask involves simply bolting a thick metal lid to the body of the cask just as metal casks are sealed (DOE 1989a, 1-52).

Ventilation also can be accomplished in different ways. Unventilated casks rely on radiation, conduction, and natural convection to remove the heat produced by the spent fuel. Ventilated casks, in contrast, contain inlet and outlet airflow ducts to facilitate heat transfer. Because heat is removed more rapidly, the concrete of the cask wall remains at a lower temperature than it would in an unventilated cask with the same capacity. This increased efficiency in heat transfer allows ventilated casks to hold more fuel: They can hold 24 PWR or 56 BWR assemblies or canisters, run about 12 feet in diameter by 20 feet long, and weigh nearly 125 tons when loaded. Because of the weight of these casks, and because concrete is more difficult to decontaminate, concrete casks are usually loaded following a dry rather than a wet procedure (see the description of wet and dry loading in the section on metal casks) (DOE 1989a, l-53).

The costs for dry storage in concrete casks are somewhat uncertain. As the technology becomes more refined, however, DOE expects the manufacturing cost for concrete casks eventually to be less than the cost for motal casks (DOE 1989a, 1-54). The total cost of dry storage in concrete casks is made up of the same factors used to estimate costs for metal casks. As with metal casks, the acquisition of the casks is the single greatest component of the unit cost of storage.

DOE'S estimates assume the costs of licensing ISFSIs that use concrete casks to be the same as the licensing costs

\begin{tabular}{|lccc|}
\hline \multicolumn{4}{|c|}{$\begin{array}{c}\text { Table 8. DOE Unit-Cost Estimates for } \\
\text { Additional Storage Requirements }\end{array}$} \\
\hline & \multicolumn{3}{c|}{ Capacity increase } \\
\hline Storage technology & 100 MTHM & 300 MTHM & 1000 MTHM \\
\hline $\begin{array}{l}\text { Consolidated fuel stored } \\
\text { in reactor pool }\end{array}$ & $40-75^{\circ}$ & $30-50$ & NA \\
Modular concrete vault & $105-155$ & $70-105$ & $45-70$ \\
Horizontal concrete module & $60-80$ & $45-60$ & $40-55$ \\
Metal cask & $60-115$ & $55-105$ & $55-100$ \\
Concrete cask & $50-110$ & $45-95$ & $45-85$ \\
\hline
\end{tabular}

${ }^{3}$ For a breakdown of costs into variable and fixed costs, see Appendix 5. 'All numbers are in dollars per kilogram of heavy metal. Dollar figures are not adjusted for inflation.

Source: DOE 1989a, 1.86.

incurred for metal casks. The initial cost of constructing a storage facility is also expected to be the same. Cask costs, however, are expected to be lower, ranging from $\$ 40$ to $\$ 60$ per kilogram of heavy metal. DOE calculated high and low unit costs for storage based on estimates for dry and wet loading, respectively. The high estimate includes an additional $\$ 400,000$ in equipment costs (for fuel canisters and a transfer cask) and an extra $\$ 3$ per kilogram for loading costs. ${ }^{25}$ The total fixed costs for this method of storage thus range from $\$ 800,000$ to $\$ 2.4$ million, with total variable costs ranging from $\$ 45$ to $\$ 85$ per kilogram of heavy metal. In terms of average unit cost, dry storage in concrete casks may cost from $\$ 50$ to $\$ 110$ per kilogram for a capacity of $100 \mathrm{MTHM}$ and $\$ 45$ to $\$ 85$ per kilogram for a capacity of 1,000 MTHM (see Table 8) (DOE 1989a, l-55).

\footnotetext{
${ }^{25}$ Loading costs increase because the fuel is assumed to be placed in canisters before being loaded into the concrete casks (DOE 1989a, I-55).
} 
DOE entered into a cooperative agreement with EPRI and the Wisconsin Electric Power Company to test a ventilated storage cask (VSC-17) designed by Pacific Sierra Nuclear Associates. The VSC utilizes a multi-assembly sealed basket capable of housing from 4 to 24 PWR assemblies or 9 to 56 BWR assemblies. Although the models with greater capacity are more economical, the smaller sizes may be used at nuclear plants with limited crane capacity (Chechelnitsky et al. 1057).

The VSC-24 has been selected by Consumers Power Company for use in an ISFSI at the Palisades Nuclear Plant near South Haven, Michigan. The NRC recently issued a final rulernaking that adds the VSC-24 cask to the list of casks approved for general use under 10 CFR 72, Subpart K (NRC 1993). With the certification of the VSC-24 cask, the Palisades ISFSI is poised to become the first installation to take advantage of the NRC's general license provisions (for further information on the Palisades ISFSI, see the section on Midwestern reactors). The Wisconsin Electric Power Company also plans to use VSC casks for an ISFSI at its Point Beach Nuclear Plant in east-central Wisconsin (Chechelnitsky et al. 1042).

Dual-purpose casks. Combining storage and transportation functions in a single cask can offer several advantages to utilities and to DOE. A utility can store spent fuel in the cask for a long period of time and then ship it to a DOE facility without having to unload and transfer the fuel to a shipping cask. The appeal of dual-purpose casks is that their use can significantly decrease the handling of spent fuel and, thus, reduce operating costs, worker exposure, and the potential for accidents (Smith 367).

Dual-purpose casks may resemble metal storage casks, with some slight differences in size and shape (DOE 1989a, I-49). Some vendors have approached the NRC with the idea of having their storage casks certified under 10 CFR 71 for use in transporting spent fuel. ${ }^{20}$ Changes may need to be made to the lid and sealing systems, though. In most cases these systems are designed to meet transportation requirements; however, the ability of the systems to meet these requirements after long-term storage may need to be demonstrated. The basket and body of the cask may also need to undergo modification to comply with the NRC's standards for accident conditions (DOE 1989a, I-49).

According to DOE, the cost of dual-purpose casks will exceed that of metal casks by approximately $\$ 7$ per kilogram of heavy metal for intact assemblies. The cost includes engineering, design, licensing, and amortization, and reflects a sa vings of $\$ 1$ per kilogram in loading and inspection costs (DOE 1989a, I-50). A different study calculated the costs based on the costs of design, development and licensing, production cost per cask, cask capacity, and the number of casks manufactured. The report concluded that the cost per kilogram of heavy metal stored could range from $\$ 42$ (for a capacity of 3,000 MTU) to $\$ 110$ (for 100 ) MTU) (Smith 368). The greatest determinant of unit cost in this study was the production cost of manufacturing the casks.

While dual-purpose casks have been used in Germany, their use has not yet been approved in the United States. For several years, the NRC has been reviewing the design of the NAC dual-purpose cask for licensing purposes. The cask uses conventional materials (e.g., lead, stainless steel), but the design does not rely on either boron or burnup credit in criticality analysis. Including boron or burnup credit would reportedly increase the capacity of the cask from $12 \mathrm{MTU}$ to $17 \mathrm{MTU}$, decreasing unit costs in the process. Another way to reduce cask costs is to replace stainless steel with a less expensive material having similar

${ }^{26}$ As discussed in the previous section on licensing, certification for storage purposes takes place under 10 CFR 72. 
properties. Ferritic steel and nodular cast iron are being investigated as potential substitutes (Smith 368).

Multi-purpose canister systems. These multi-purpose casks combine storage, transportation, and disposal in one container. The multi-purpose canister system would potentially allow spent fuel to be stored in a single canister for storage, transport, and disposal, utilizing separate overpacks for each of these functions. Although not yet developed in the United States, the Secretary of Energy, in a December 1992 letter to the Chairman of the Senate Committee on Energy and Natural Resources, included such casks in a new strategy for using existing federal facilities for monitored retrievable storage of spent fuel. The Secretary announced his intention to "refocus [DOE's] spent fuel container design activities on development of a slandardized system with capability for receipt, dry storage, transport, and disposal of spent fuel" (Watkins 2). According to the Secretary, the containers developed under this program may be able to "reduce costs, minimize required handling of spent fuel assemblies, and provide more efficient storage at both an interim storage site and nuclear plant sites" (Watkins 1). The viability of such a system, however, has not yet been determined.

\section{TRANSPORTATION IMPACTS OF INTERIM STORAGE}

DOE examined the potential effects of at-reactor storage on the costs and risks associated with transporting spent fuel after dry storage. ${ }^{27}$ The department concluded that all but two of the dry storage options would not affect transportation. The two that were found to have a possible impact are rod consolidation and dual-purpose casks. ${ }^{28}$

Consolidation of fuel can reduce the number of shipments because more fuel is contained in a smaller space. The weight of the added fuel, however, limits the extent to which consolidation offers an advantage. Rail shipments, for example, are subject to a weight limit of $263,000 \mathrm{lbs}$. for unrestricted transport, which amounts to an increase of $33 \mathrm{to}$ 50 percent in the quantity of spent fuel that can be shipped for PWR and BWR fuel, respectively (DOE 1989a, I-101). ${ }^{29}$ Truck shipments are subject to a legal limit of 80,000 l'bs., with present cask designs limited to 3 PWR or 7 BWR assemblies regardless of form. As a result, the number of truck shipments is not likely to decline as a result of rod consolidation.

Consolidation also produces canisters of compacted hardware, which emit more gamma radiation than canisters of consolidated fuel and, consequently, will produce higher gamma dose-rates at the surface of the cask (DOE 1989a, 1-100). For non-fuel-bearing hard ware, then, cask capacities are limited less by weight than they are by radiation characteristics. DOE indicated that in the event utilities increasingly turn to rod consolidation to solve their storage problems, the casks used to transport spent fuel are likely to be modified to increase capacity, in turn reducing both the number of shipments and the radiation exposure received by the public (DOE 1989a, I-101).

${ }^{27}$ Pool sturage is assumed to be the base case.

${ }^{28}$ DOE's Final Dry Cask Storage Study, conducted in 1989, did not examine the potential impact of multi-purpose canisters on the transportation system. Presumably, the costs and benefits of these casks would be similar to those of dual-purpose casks.

${ }^{29} \mathrm{DOE}$ calculated the gain in capacity to increase from 21 to 28 assemblies for IWR fuel and from 48 to 72 assemblies for BWR fuel (DOE 1989a, I-101). 
Dual-purpose casks may affect the transportation program by reducing the costs DOE incurs to purchase transportation casks. DOE calculated that the maximum benefit of using dual-purpose casks "would be realized if a sufficient number of utilities agree to transfer the ownership of ! thel casks in time to preclude the purchase of transportation casks by the DOE" (DOE 1989a, I-100). This conclusion is based on a scenario in which dualpurpose casks are used to meet all the spent-fuel storage requirements at reactor sites that are capable of handling rail or barge casks and are directly accessible by rail. Assuming only 28 to 34 casks are transferred to DOE over the lifetime of the program, DOE estimated the possible savings to be as high as $\$ 25$ to $\$ 35$ million. If DOE were to use dual-purpose casks for lag storage at its waste management facilities, further savings might be realized (DOE 1989a, l-100). At this time, however, no utilities are utilizing dual-purpose casks.

\section{INTERIM STORAGE AT MIDWESTERN REACTORS}

According to DOE's Spent Fuel Storage Requirements 1991-2040, seven Midwestern reactor pexols were projected to lose FCR within the next five years. This section discusses the actions taken or proposed by the utilities that own or operate the reactors in question. The information contained in the discussion was obtained through interviews with personnel at each of the plants. Spent-fuel inventories, pool capacities, and projected dates for loss of FCR may not match those listed in DOE's report.

\section{Big Rock Point (Charlevoix, Michigan)}

Owned and operated by the Consumers Power Company (CPC), the Big Rock Point plant is expected to lose FCR in 1996. The plant's storage pool was reracked in the mid1980s, which increased its maximum capacity from 193 to 441 BWR assemblies. A total of 294 of these slots are currently filled.

CPC considers dry storage to be both economically and politically infeasible at Big Rock Point. The plant is scheduled to shut down on May 31, 26(k), therefore the plant managers are studying the option of operating the facility without maintaining FCR. In the event of an emergency situation that would otherwise require the removal of the entire core, the plant would immediately shut down.

\section{Donald C. Cook (Bridgman, Michigan)}

With 1,600 of its 2,050 licensed storage slots full, the Cook plant was projected to lose FCR in mid-1995. After reviewing its options for increasing on-site storage capacity, the Indiana-Michigan Power Company (IMPC) decided dry cask storage was too expensive and rod consolidation would be infeasible given the year-round investment of time required to perform the operation. The company chose instead to rerack the storage pool shared by the two reactors at the plant. Reracking will increase the pool's capacity to 3,613 assemblies.

Planning for the reracking project began in the spring of 1990 . On January 18,1993 , upon receiving a license from the NRC, IMPC began the production phase of the project, which they expect to complete by July 1993. As yet the reracking project has not met with any public opposition. The additional gain in capacity will be sufficient for the plant to operate without losing FCR through 2009 or 2010, several years short of the date the plant's operating license will expire. IMPC anticipates reinvestigating its storage options again in 2004 or 2005. 


\section{Fort Calhoun (Fort Calhoun, Nebraska)}

The storage pool at the Fort Calhoun nuclear plant currently has a maximum capacity of 729 PWR assemblies. The remaining space is sufficient to enable the plant to operate until 1995 before losing FCR. In December 1992, the Omaha Public Power District applied to the NRC for a license amendment to increase the capacity of the pool to 1,083 assemblies through reracking. If approved, the expansion will provide enough additional space for the plant to operate through 2006 without losing FCR. The design phase of the reracking project is complete, and the district hopes to receive NRC approval and to begin construction in the spring.

\section{Palisades (Covert, Michigan)}

CPC's Palisades plant effectively lost FCR with its last fueling cycle in 1992. Currently, only 24 storage spaces remain open in the spent-fuel pool, far short of the 204 necessary to maintain FCR. The pool has twice undergone reracking in its 21-year history, with a resulting increase in capacity from an initial 272 to 772 PWR assemblies.

In March 1990, CPC applied for a site-specific license to store spent fuel in VSC-24 concrete casks. The NRC received over 50 letters requesting a hearing on the application (Haughney 1993, 2). CPC withdrew its application for a site-specific license in August 1990 and indicated its intent to pursue dry cask storage through the NRC's newly promulgated general license provisions.

Because the VSC-24 cask had not yet received NRC certification, Pacific Sierra Nuclear Associates ${ }^{30}$ petitioned for a waiver of the requirement that cask certification must precede fabrication. The NRC granted the exemption and permitted CPC to receive from Sierra Nuclear three metal baskets and eight concrete casks. CPC requested an exemption to use the casks before certification in the event of a possible forced shutdown of the plant due to lack of adequate storage space. The request was not granted, nor does CPC face such an emergency situation.

CPC plans eventually to have a total of 25 casks in its ISFSI. The additional capacity gained through dry storage will enable the plant to maintain FCR until $2001 \%$, which is only a few years short of the expiration of its operating license. The company intends to begin loading spent-fuel casks shortly after the NRC's final rulemaking regarding the VSC-24 gores into effect on May 7, 1993. CPC has estimated the total cost of operating the ISFSI during the first three years to be $\$ 12$ million.

The construction of a dry storage facility at Palisades has generated a significant amount of public opposition. CPC provided information to the local county commission, conducted tours of the plant, and participated in discussions of the proposed storage facility. The county commission even held one of its regular meetings at the Palisades plant, with the meeting open to the public. Yet these attempts to involve the public did not quell all opposition to the project. During the public comment period for the proposed rulemaking adding the VSC-24 cask to the list of approved storage casks, the NRC received over 190 comment letters, many specifically objecting to the use of the cask at the Palisades plant (Haughney 1993, 2).

In December 1992, at the urging of environmental and anti-nuclear groups such as

\footnotetext{
${ }^{30}$ Pacific Sierra Nuclear Associates is now called Sierra Nuclear Associates.
} 
Don't Waste Michigan, State Attorney General Frank Kelly wrote to NRC Chairman Ivan Selin requesting a public hearing on the use of dry storage casks at the Palisades plant. The NRC declined to hold such a hearing; the commission did agree, however, to meet with Kelly to discuss the proposed ISFSI at Palisades. At the February 1993 meeting, Kelly declared that "the people of Michigan can be well served only by a full, formal hearing on the issues" surrounding the dry storage facility. Kelly is currently seeking the support of his counterparts in other Great Lakes states in urging the NRC to conduct a formal public hearing into the use of the VSC casks.

\section{Point Beach (Two Creeks, Wisconsin)}

Wisconsin Electric Power Company's (WEPCo's) Point Beach Nuclear Plant, in eastcentral Wisconsin, is projected to lose FCR in 1995. The storage pool shared by the plant's two reactors has a total capacity of 1,502 PWR assemblies, which represents an expansion of over 1,200 assemblies as a result of having been reracked twice. A number of the existing slots, however, are inaccessible due to interference which restricts fuel handling above the slots." As a consequence, the pool, which currently contains 1,210 assemblies, can hold only 1,415 assemblies.

WEPCo has proposed expanding its on-site storage capacity through the use of VSC-24 casks under a general license. In 1989, the utility participated with DOE in a demonstration of the VSC prototype cask at INEL. The demonstration involved storing consolidated fuel, however WEPCo does not plan to consolidate fuel for storage at the Point Beach plant.

In November 1991, WEPCo applied to the Public Service Commission of Wisconsin (PSCW) for a certificate of authority to construct 12 VSC-24 casks and a storage facility sized to hold a maximum of 48 of these casks. The storage capacity gained with the first 12 casks would take the plant through 1998 with FCR. The full 48 casks would provide sufficient onsite storage through the life of the plant. Depending on the action of the PSCW, WEPCo plans to begin facility construction in 1993 and start loading casks as early as mid-1994.

Since submitting the application nearly a year and a half ago, WEPCo has been discussing the proposal formally and informally with PSCW staff, plant neighbors, and other interested groups throughout the state. The PSCW has indicated that it, $t(0)$, will ensure that the public is involved in the review of the WEPCo dry storage proposal. As part of its treatment of the application, the PSCW plans to conduct a full environmental impact statement and to hold at least one and possibly several public hearings.

In addition, as part of the review process, interested parties in Wisconsin can apply for funding to conduct independent studies of the proposal. The utility is responsible for providing the funds for those studies approved by the PSCW. To date, three groups have applied for and received funding, and will be participating in the case. The Wisconsin Citizens Utility Board is conducting a study of the total costs of nuclear power, including both real economic costs and the costs to society. The Citizens Utility Board is concerned that DOE's slow progress in developing federal storage and disposal facilities will lead to a situation in which an ISFSI at the Point Beach plant will become a permanent storage facility, perhaps even accepting spent fuel from out of state.

"WEPCo plans to gain access to these storage slots with the purchase of special handling equipment. 
The current schedule calls for a draft of the environmental impact statement to be published this spring, followed by a 60 -day public comment period. The final environmental impact statement could be ready early this summer, with hearings to follow within another month and a PSCW order ready in the early fall.

\section{Prairie Island (Welch, Minnesota)}

The Prairie Island nuclear f'ant is expected to lose FCR in 1993, despite the fact that its two pools have both been reracked twice. The first reracking project took place in the mid-1970s and increased the storage capacity from 210 to 687 PWR assemblies. The pools were again reracked in 1981 , bringing the total capacity to its current figure of 1,386 assemblies (MEQB A-9).

In 1987, Northern States Power Company (NSP) conducted a demonstration of rod consolidation at the Prairie Island plant in conjunction with Westinghouse (DOE 1989a, 167). The purpose of the demonstration was to help NSP gain the experience necessary to evaluate whether or not rod consolidation would be capable of meeting Prairie Island's long-term storage needs. The rods from 36 PWR assemblies were consolidated into 18 canisters, which are now stored in the pool.

NSP decided not to pursue the option of rod consolidation for two reasons. First, the company determined that consolidation could not meet life-of-plant storage needs, which would probably be necessary given DOE's slow progress in developing federal facilities for storage and disposal. Second, because it is a time-consuming operation that would take place in the fuel pool for six months out of the year, rod consolidation would likely interfere with plant operations (MEQB A-9).

NSP submitted a license application to the NRC in September 1990. The Minnesota Department of Public Service and the Environmental Quality Board filed a petition to intervene in the licensing proceedings. In March 1991, however, these agencies entered into a Stipulation Agreement with the NRC, NSP, and the Prairie Island Indian Community (Sturz 5).

In 1991, NSP applied to the Minnesota Public Utilities Commission (MPUC) for a certificate of need to allow construction of an on-site dry storage facility. ${ }^{32}$ NSP proposed building a facility consisting of 48 metal casks (Transnuclear's TN-40 model) that would hold spent fuel aged at least 10 years. In August 1992, the MPUC approved the use of only 17 casks at the site, which will allow the plant to operate until the year $2(X)$ without losing FCR. The commission's decision requires NSP to maintain FCR for both reactors at the plant. In addition, annual progress reports on DOE's activities with regard to developing an MRS facility must be submitted to the commission.

As part of the permitting process, the Minnesota Environmental Quality Board performed an environmental impact statement for the proposed site. ${ }^{33}$ The Minnesota Department of Health provided input in the form of a health-risk assessment of the sturage facility to determine acceptable off-site dose limits to the nearest permanent resident. The

${ }^{32} \mathrm{~A}$ certificate of need is required pursuant to Minnesota Rules, Chapter 7855 (MEQB 2.1).

"An environmental impact statement is not required by Minnesota law, rather the Envirunmental Quality Board prepared the study pursuant to a voluntary agreement with NSP (Sable 362 363). 
Department of Health decided upon a limit of 0.054 mrem per year as a maximum, compared to the federal limit of 25 mrem per year. ${ }^{34}$

NSP was able to ensure compliance with this limit by relocating the facility from the proposed site in the northwest corner of the property to the southwest corner. The cost associated with altering the facility design and with construction requirements at the new site amounted to $\$ 1$ million. Although it has chosen to meet the Department of Health's dose limits, NSP hopes the state will either remove the requirement from the permit approval or issue the limit in a formal rulemaking.

Construction of the site began in 1992 and is currently 50 percent complete. NSP plans to resume construction in the spring of 1993 and expects to receive a license from the NRC in April or May. The company has placed an order with Transnuclear for seven casks, which are currently being fabricated. Barring any unforeseen delays, NSP expects to begin loading spent fuel in the early months of 1994.

NSP's request to store spent fuel in casks did not meet with any opposition at the federal level. Within the state of Minnesota, however, the Prairie Island Sioux tribe and the Coalition Against Nuclear Storage intervened before the MPUC to oppose the issuance of a permit to construct the storage facility. After the MPUC granted NSP a permit for a limited number of casks, the Prairie Island tribe, the Coalition, and the Minnesota Public Interest Research Group (formerly a member of the Coalition) appealed to the Minnesota Appeals Court, which is expected to issue a decision in May or June of 1993.

In addition to its lawsuit against the MPUC, the Prairie Island tribe sought to block the storage facility by enforcing its radiation-control ordinance. Through this ordinance, the tribe regulates the transport of radioactive materials through the Prairie Island reservation as well as within a certain distance of the reservation. The Prairie Island tribe has filed an appeal with the Eighth U.S. Circuit Court to reverse a decision by a lower court to bluck enforcement of the tribal ordinance.

\section{Zion (Zion, Illinois)}

The Zion plant in northeastern Illinois currently has a maximum capacity of 2,(174 PWR assemblies, with 631 slots remaining empty. The existing storage space is sufficient to allow the plant to operate until 1997 without losing FCR. Commonwealth Edison Company is planning a reracking project that will expand the storage pool's capacity to 3,006 slots, adding enough additional space to accommodate storage needs through the year 20107. The project was scheduled to begin March 1, 1993, and will be completed in mid-August.

\footnotetext{
${ }^{4}$ The nuclear plant does not itself meet the dose limit set by the Department of Health, nor is it required to do so.
} 


\section{REFERENCES}

\section{Documents}

Carter, Luther. 1987. Nuclear Imperatives and Public Trust: Dealing arith Radivactive Waste. Washington, DC: Resources for the Future.

Chechelnitsky, Boris A., J. Steve Nunez, John V. Massey, and Charles J. Purnell. 1990. Concrete cask storage technology. In Procedings of the First Ammual International Topical Meeting on High-Level Radioactive Waste Management. LaCrange, IL: American Nuclear Society and American Society of Civil Engineers; pp. 1037-1042.

General Accounting Office (GAO). 1988. Information on the Reracking of the Diablo Canyon Spent Fuel Storage Pools. Washington, DC: U.S. General Accounting Office. GAO/ RCED-88-79FS.

Haughney, Charles J. 1992. Spent Fuel Licensing. Presentation before the Western Interstate Energy Board High-Level Waste Committee (Denver, CO; October 1).

1993. Letter to Lisa R. Sattler (comments on draft of Report on Interim Storage of Spent Nuclear Fuel). March 9.

Holt, A.J. 1990. A modular vault dry storage facility for Fort St. Vrain. Reprinted from Nuclear Engineering International (October).

Johnson, E.R. 1990. Choosing at-reactor spent fuel storage technologies. In Proceedings of the First Anmual International Topical Meeting on High-Level Radioactive Waste Management. LaGrange, IL: American Nuclear Society and American Suciety of Civil Engineers; pp. 1030-1036.

Lambert, Ray. 1992. Comsiderations in Selecting a Spent Fuel Storage Technology. Presentation before the WIEB High-Level Waste Committee (Denver, CO; October 1).

McConaghy, W.J., R.A. Lehnert, and R.W. Rasmussen. 1991. Design and operation experience of the NUHOMS-24P spent fuel storage system. In High Livel Radioactive Waste Management: Proceedings of the Second Anmual International Conference. LaGrange, IL: American Nuclear Suciety and American Suciety of Civil Engineers; pp. 38()-387.

Minnesota Environmental Quality Board (MEQB). 1991. Environmental lmpact Statement: Prairie Island Independent Spent Fuel Storage Installation.

Nuclear Waste Policy Act, as amended. P.L. 97-425 (January 7, 1983), as amended by Title V of P.L. 100-203 (December 22, 1987).

OECD Nuclear Energy Agency (NEA). 1986. Nuclear Spent Fuel Managennent: Experience and Options. Paris: OECD.

Resnikoff, Marvin. 1983. The Next Nuclear Gamble: Transportation and Storage of Nuclear Waste. New York: Council on Economic Priorities.

Roberts, John P. 1990. Dry Spent Fuel Storage Licensing at Reactor Sites. Invited paper for the Institute of Nuclear Materials Minagement Spent Fuel Management Seminar VII (January 17-19). 
Sabel, Gretchen, and Robert Halstead. 1991. State Environmental Review of a Proposed Utility Independent Spent Fuel Storage Installation. In High Level Radiouctive Waste Manugement: Procedtings of the Second Ammual International Conference. LaGrange, IL: American Nuclear Society and American Society of Civil Engineers; pp. 362-366.

Smith, Marvin L. 1991. Standardized, utility-DOE compatible, spent fuel storage-transportation systems. In High Level Radioactive Waste Management: Proceedings of the Second Anmual Internationul Conference. LaGrange, IL: American Nuclear Society and American Society of Civil Engineers; pp. 367-371.

Sturz, Frederick C. 1992. Dry Spent Fud Storage Licensing. Presentation before the Institute of Nuclear Materials Management Fuel Management Seminar IX (Washington, DC; January 15-17).

Sturz, Frederick C., Ralph H. Sievers, and John R. Stokley. 1992. Experience with spent fuel storage licensing. In High Level Radiouctive Waste Management: I'roceeding' of the Third International Comforemce. LaCirange, IL: American Nuclear Socicty and American Society of Civil Engineers; pp. 220-227.

U.S. Department of Energy (DOE). 1989a. Final Version Dry Cask Storage Study. Washington, DC: Office of Civilian Radioactive Waste Management. DOE/RW-0220.

- 1989b. Report to Congress on Reassessment of the Civilian Radioactive Waste Management Program. Washington, DC: Office of Civilian Radioactive Waste Management. DOE/ RW-0247.

- 1991. Spent Fuel Storage Requirements 1991-2040. Richland, WA: DOE Richland Field Office. DOE/RL-91-54.

- 1993a. 1992 Ammual Capucity Report. Washington, DC: Office of Civilian Radioactive Waste Management. DOE/RW-(1)412.

. 1993b. OCRWM Bulletin (Winter). Washington, DC: Office of Civilian Radionactive Waste Management. DOE/RW-(0405.

U.S. Nuclear Regulatory Commission (NRC). 1990. Waste confidence decision review. 55 Federal Register 38474-38514 (September 18).

1992a. Code of Federal Regulations, Volume 10, Parts 51 to 199. Washington, DC: U.S. Government Printing Office.

_ 1992b. List of approved spent fuel storage casks: Additions (Proposed Rulemaking). 57 Federal Register 28645-28647 (June 26).

_ 1993. List of approved spent fuel storage casks: Additions (Final Rulemaking). 58 Federal Register (April 7).

Viebrock, J.M., and N. Mote. 1992. Facility Interface Capability Assessment (FICA) Summary Report. Norcross, GA: Nuclear Assurance Corporation. ORNL/Sub/86-97393/7.

Watkins, James. 1992. Letter to Honorable J. Bennett Johnston (Chairman, Senate Committee on Energy and Natural Resources). December 17. 
Western Interstate Energy Board (WIEB). 1992. Briefing Materials for the High-Level Waste Committee Meeting (Denver; September 31-October 1).

Wood, T.W. 1990. Spent Fuel Storage Requirements for Nuclear Utiities and OCRWM. In Proceedings of the First Anmual International Topical Meeting on High-Level Radioactive Waste Management. LaGrange, IL: American Nuclear Society and American Society of Civil Engineers; pp. 1016-1025.

\section{Interviews}

Bronicki, Doug (Radiation Protection Supervisor, IMPC/Cook Nuclear Plant), January 19, 1993.

Ferguson, Mark (Project Engineer, IMPC/Cook Nuclear Plant), January 19, 1993.

Gautier, Mark (Manager, Media Relations and Publications, Omaha Public Power District/ Fort Calhoun Plant), January 29, 1993.

Kapitz, Jon (Project Manager, Dry Cask Storage, NSP/Prairie Island Plant), January 26, 1993.

Petrosky, Tim (Public Affairs Director, CPC/Big Rock Point Nuclear Plant), January 19, 1993.

Rauh, Jeff (Nuclear Information Coordinator, WEPC/Point Beach Plant), January 26, 1993.

Savage, Mark (Public Affairs Director, CPC/Palisades Nuclear Plant), January 19, 1993.

Wakeman, Brian (Staff Engineer, Virginia Power/Surry Plant), February 1, 1993.

Wald, Gary (Spokesman, Commonwealth Edison/Zion Nuclear Plant), January 25, 1993.

Zabransky, Dave (WEPCo/Point Beach Plant), February 1, 1993. 


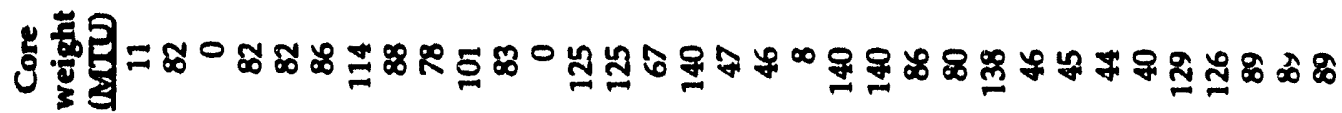

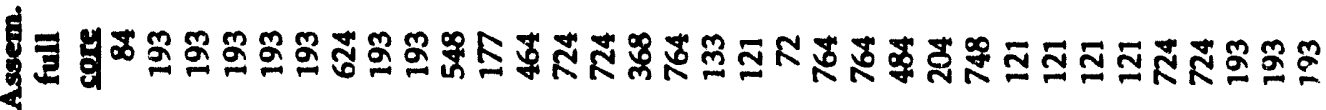

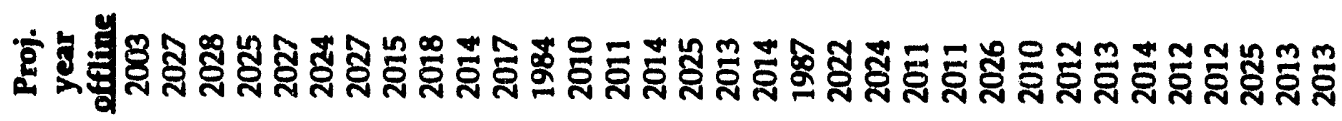

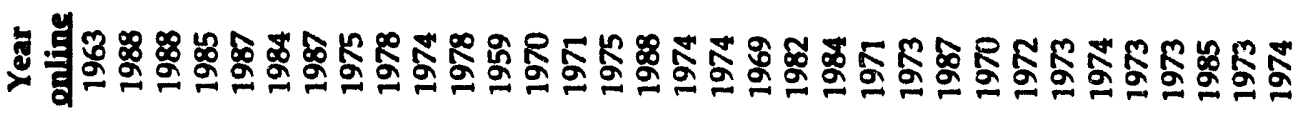

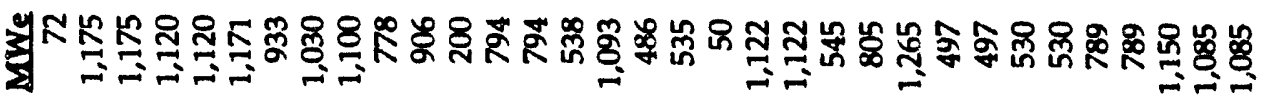

सx

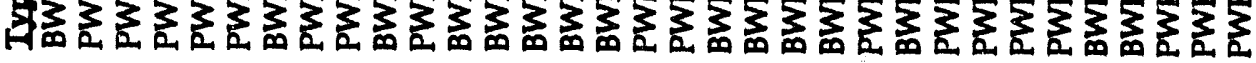

$\dot{\jmath} \dot{\jmath} \dot{0} \quad \dot{8} \dot{0}$

论

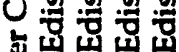

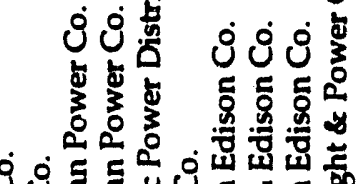

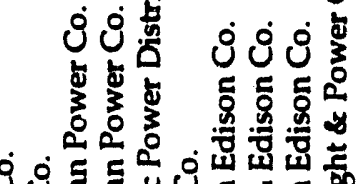

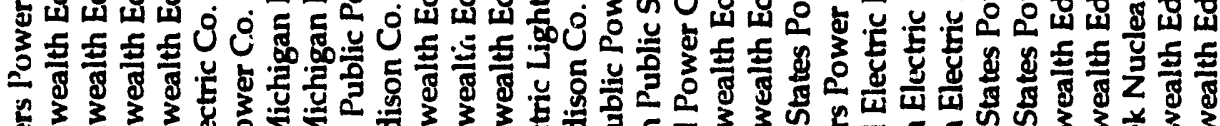

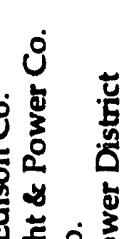

نं

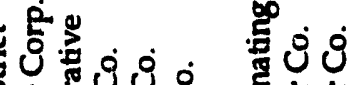

$+\dot{0} \dot{0}$ \&

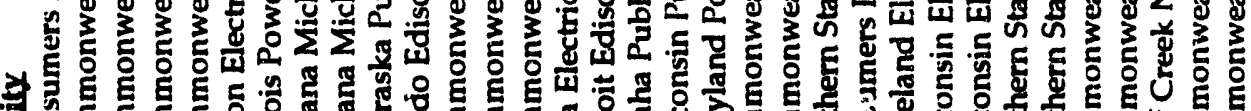

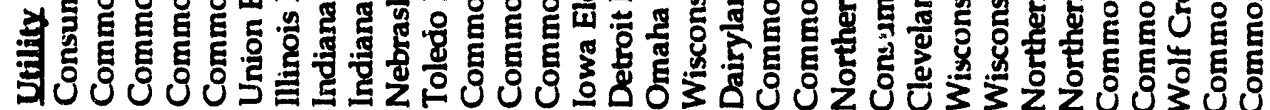

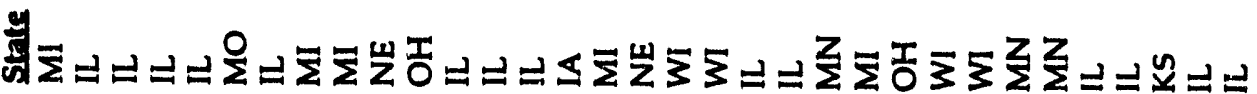

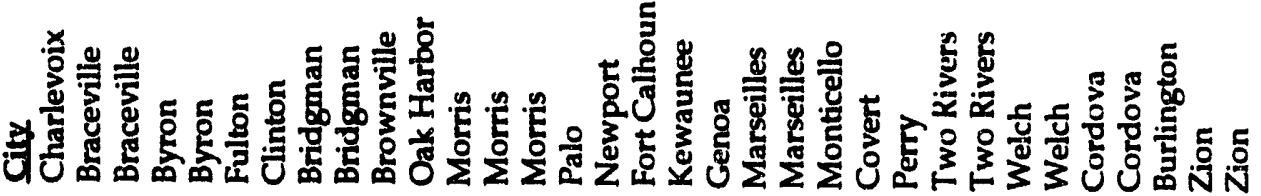

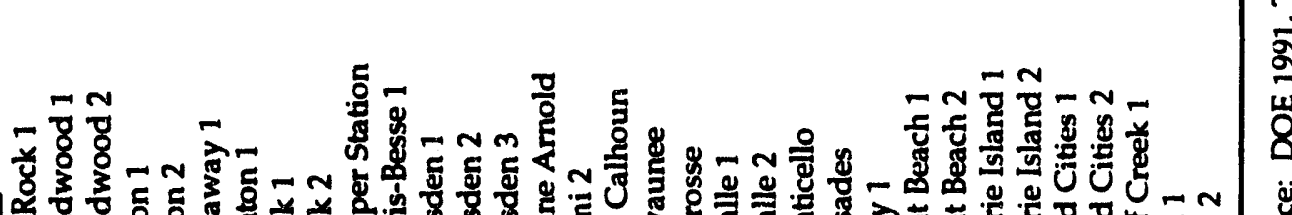

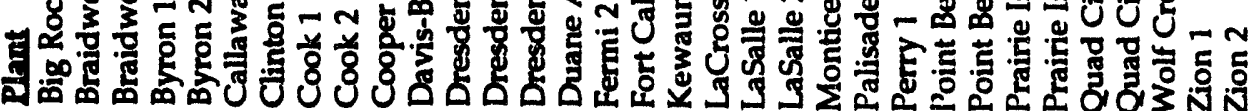




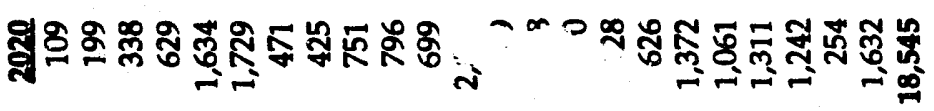

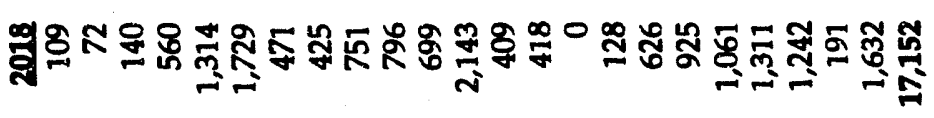

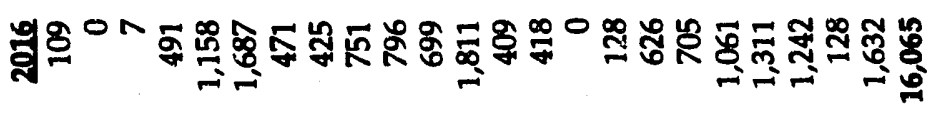

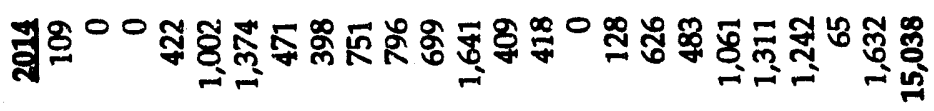

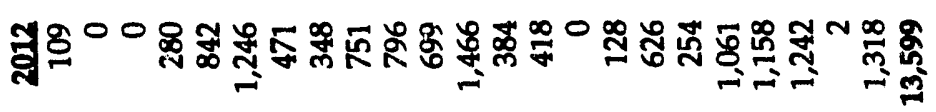

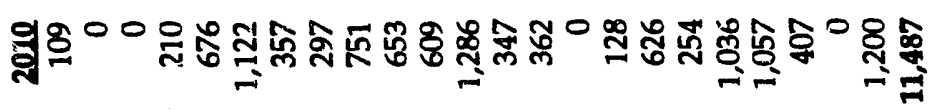

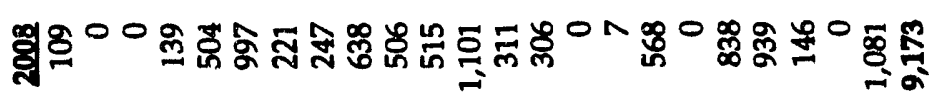

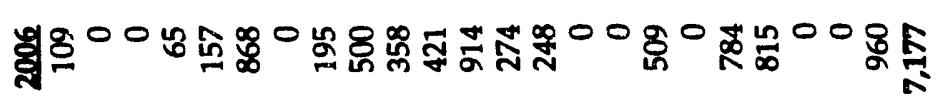

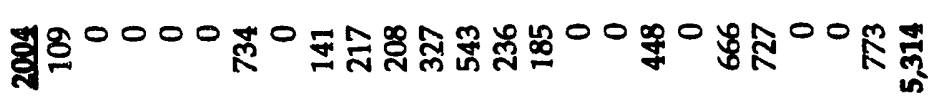
盘

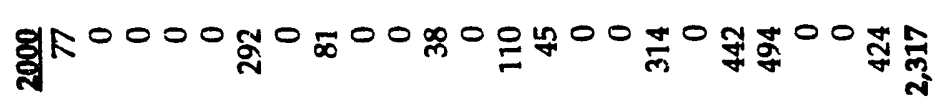

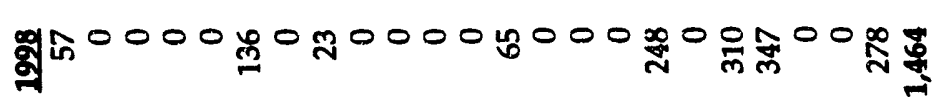
gin gू $\$ 0000000000000000 \$ 000000 \%$

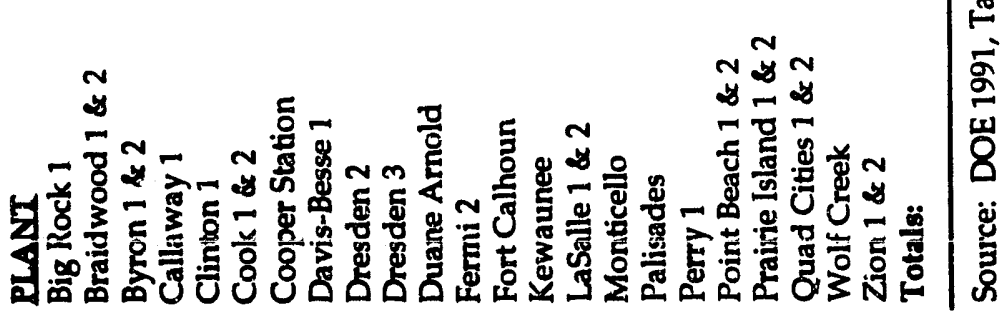




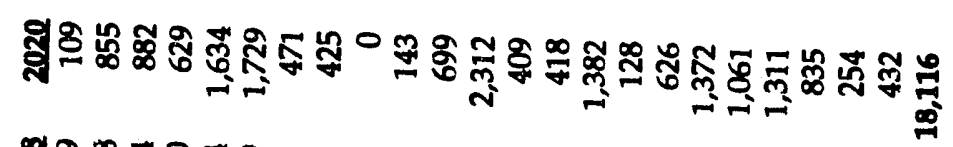

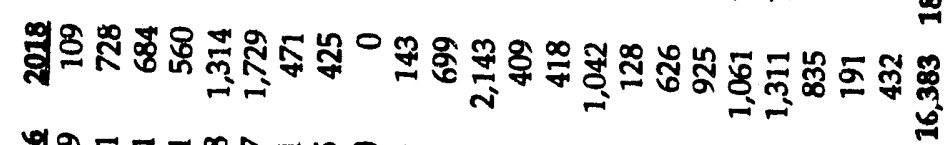

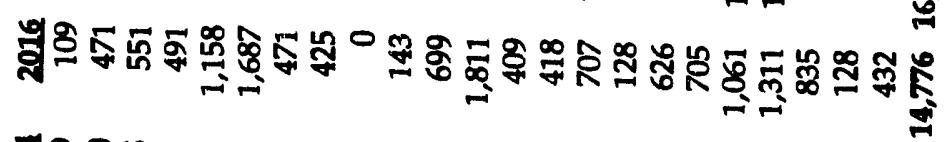

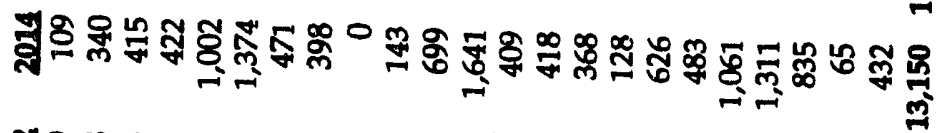

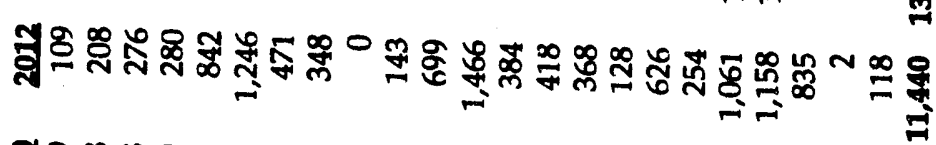

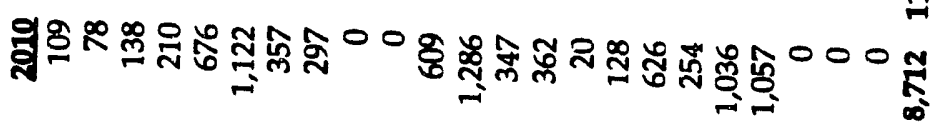

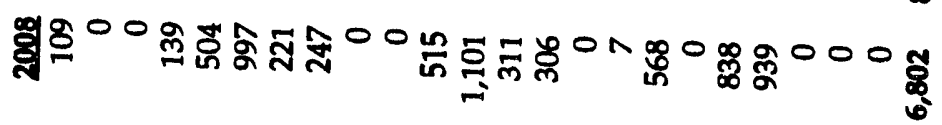

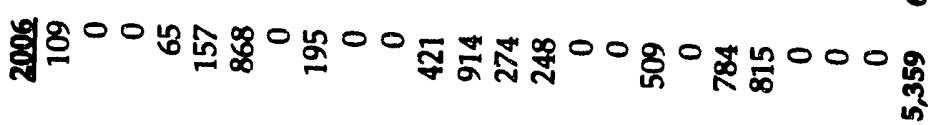

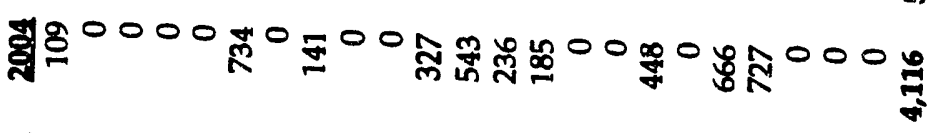

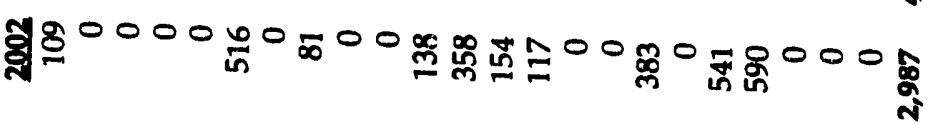

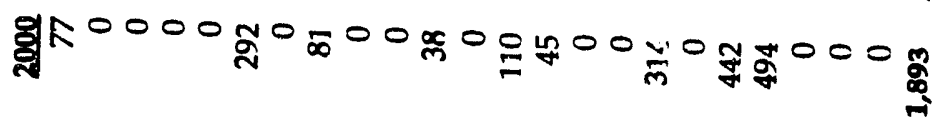

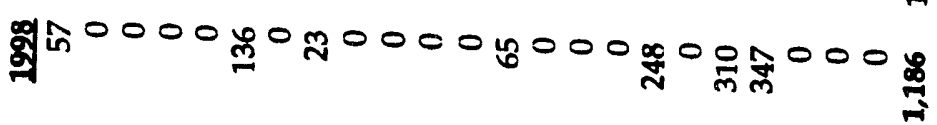

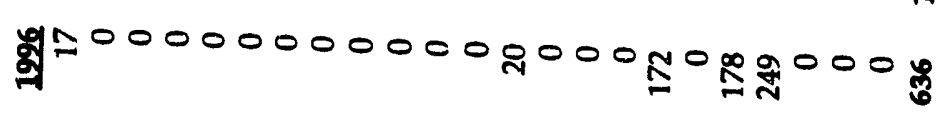

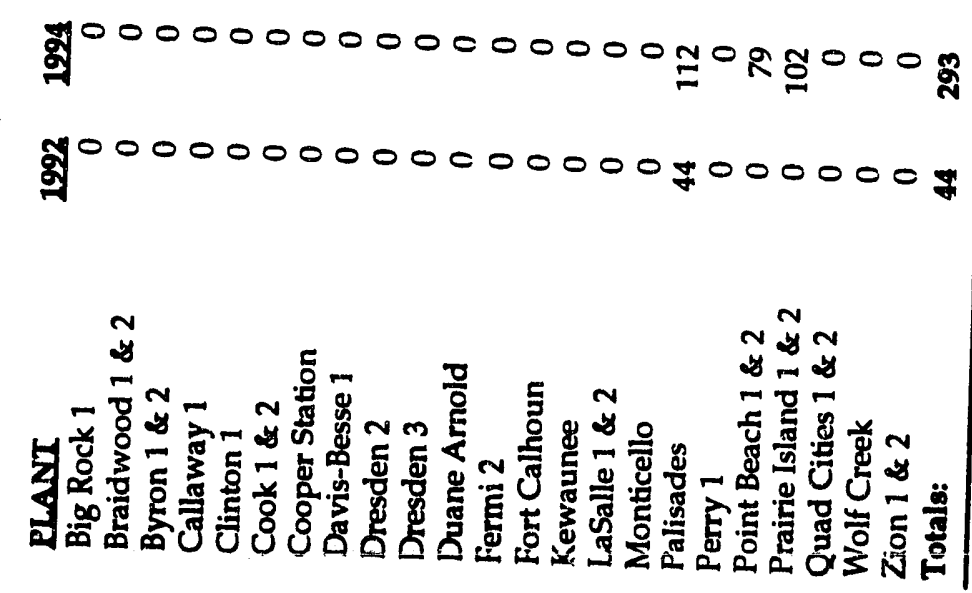




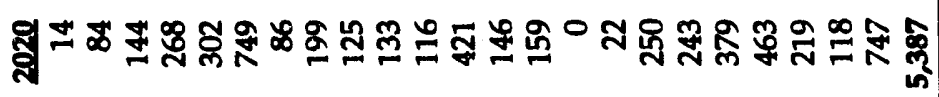

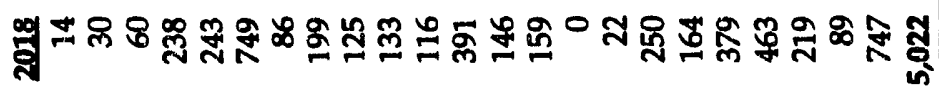

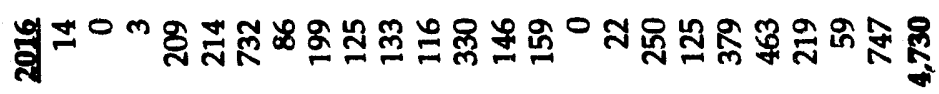

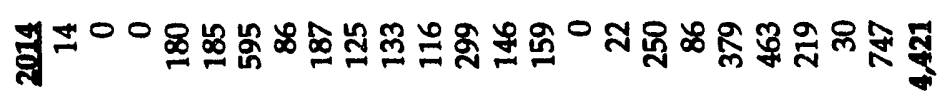

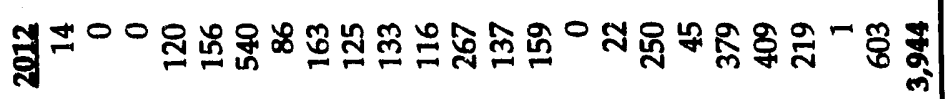

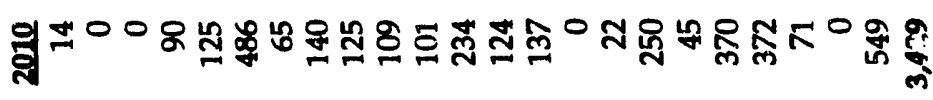

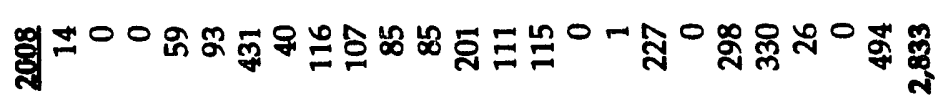

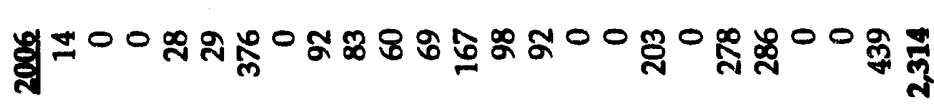
핵

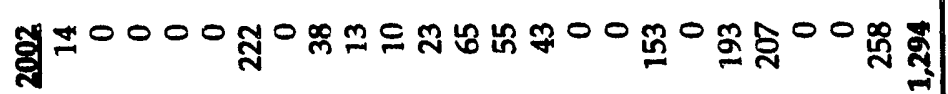

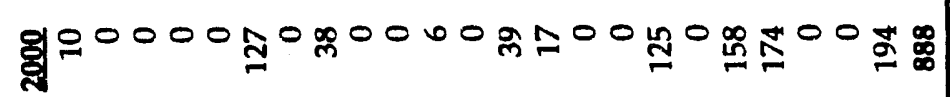

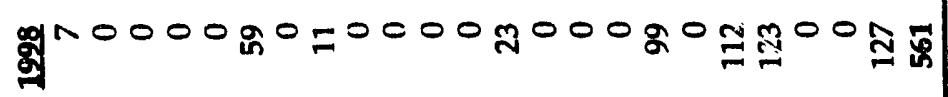

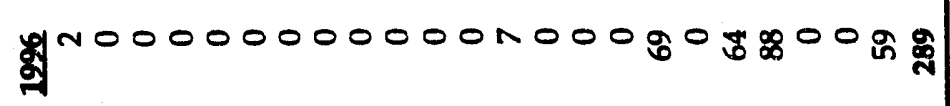
\$్耳 0000000000000000 \&0 \$00000000000000000000000

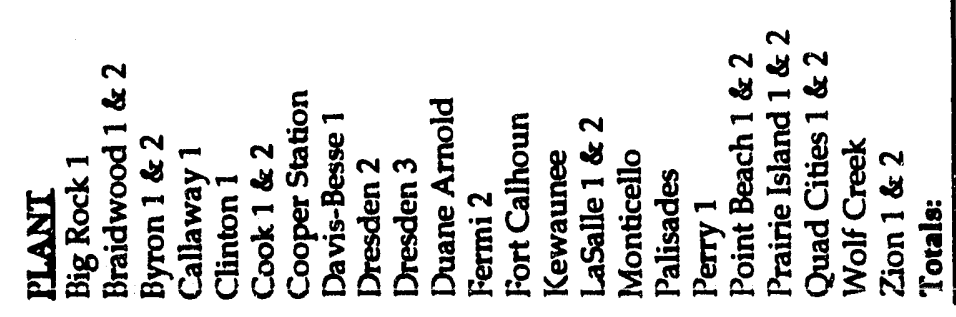




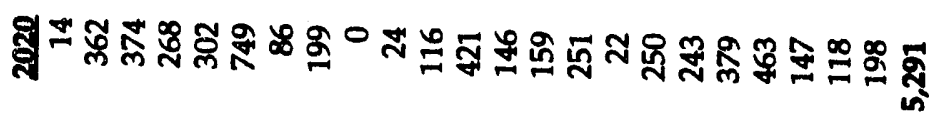

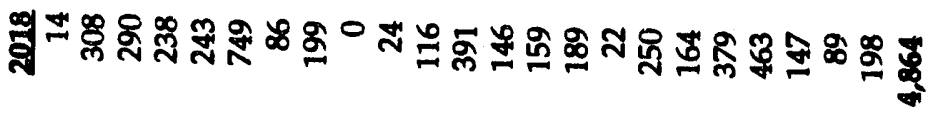

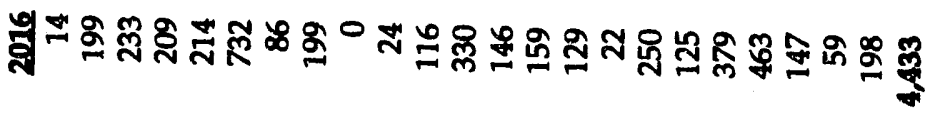

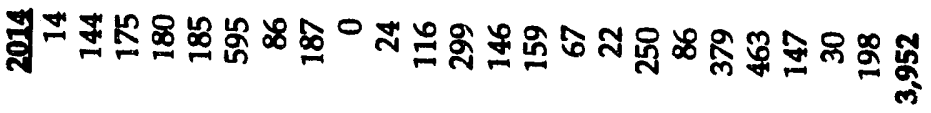

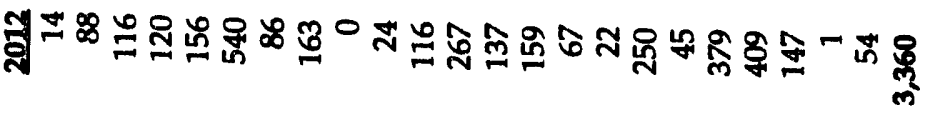

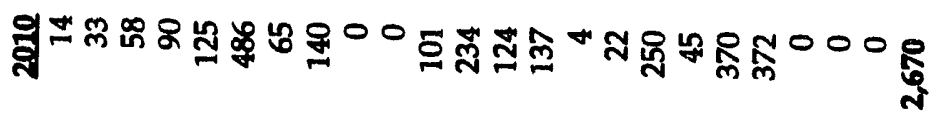

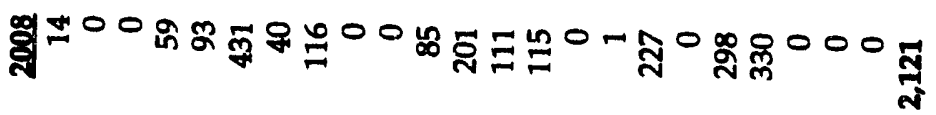

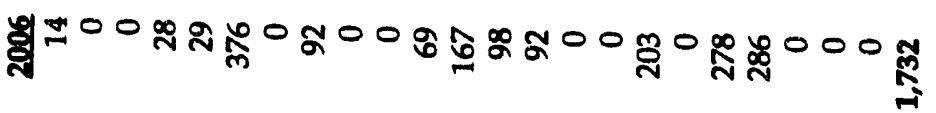

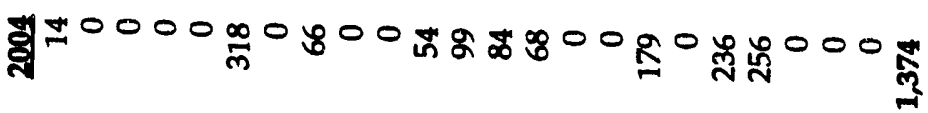

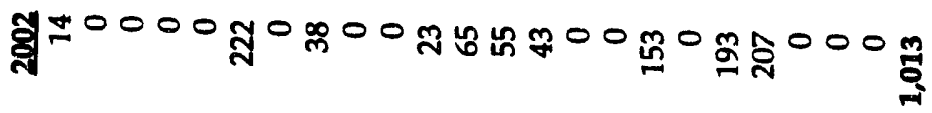

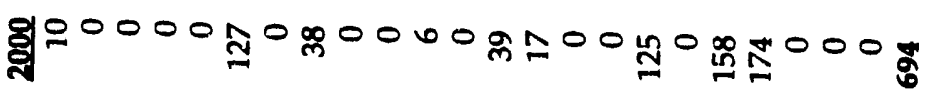

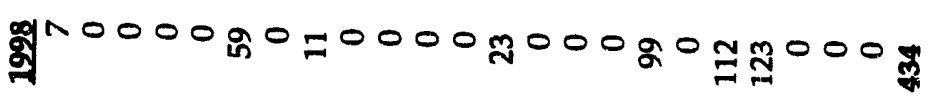

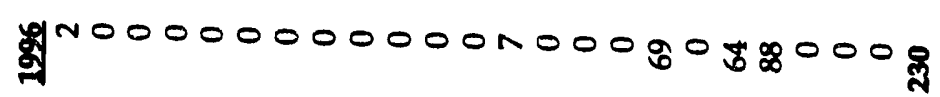
ఫ్70000000000000000\%0 \$0 $00000000000000000000000 \%$

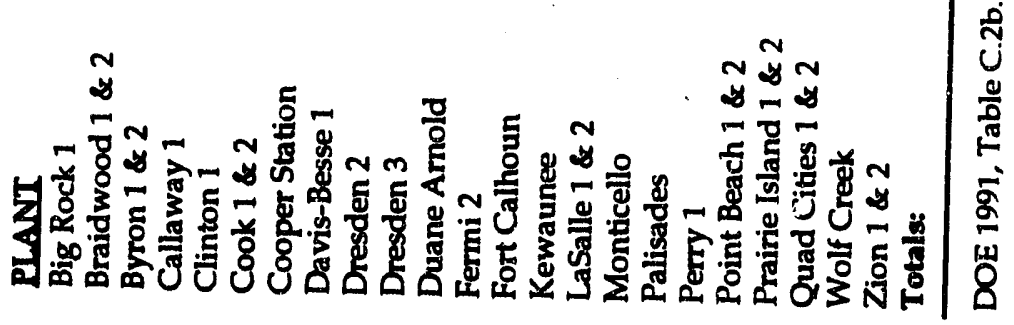




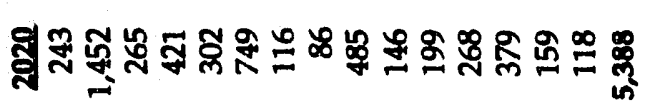

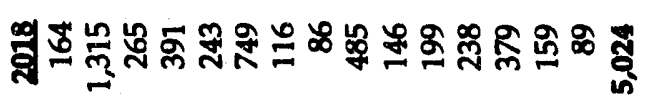

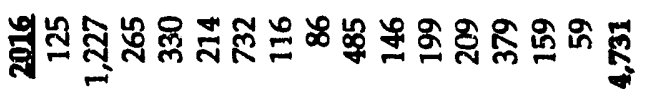

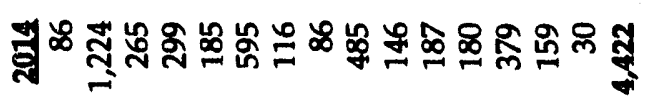

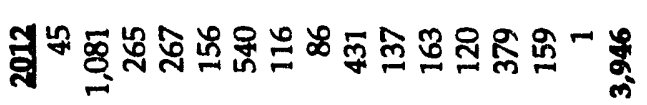

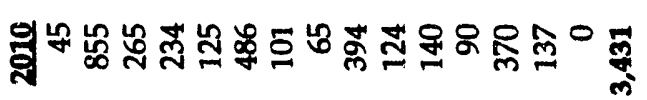

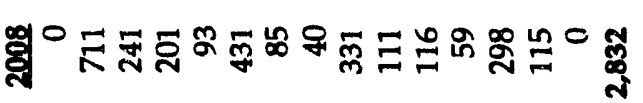

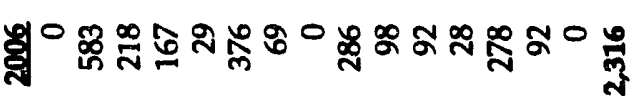

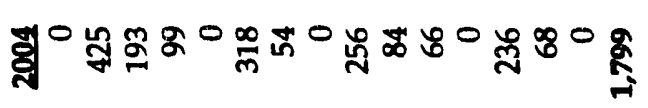

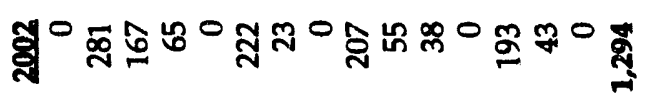

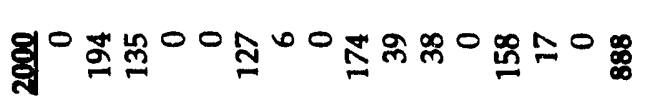

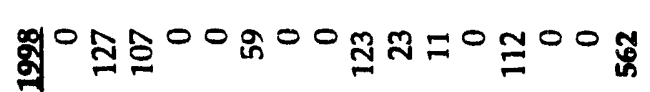

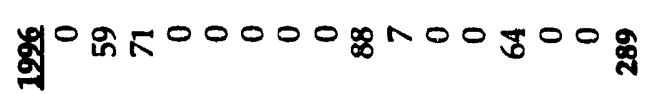

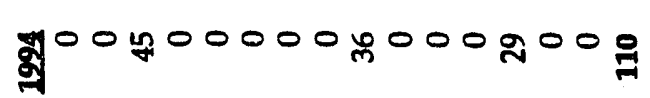
\$ $00000000000000 \%$ 


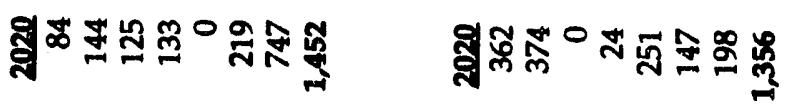

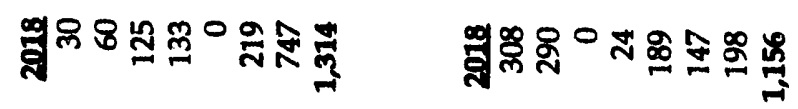

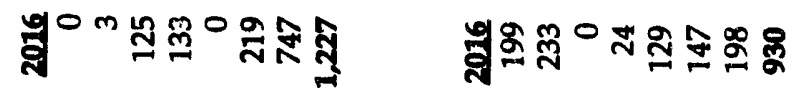

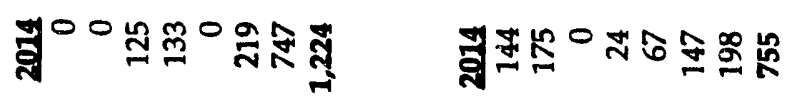

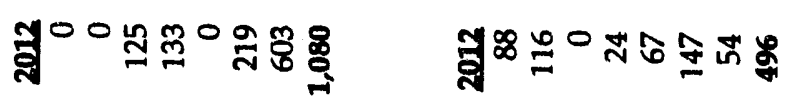

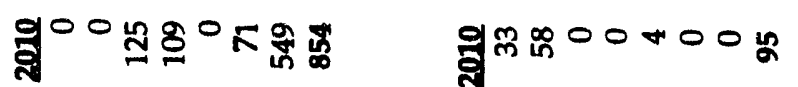

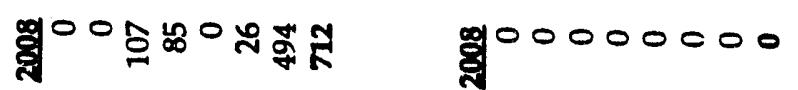

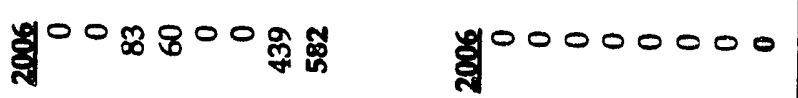

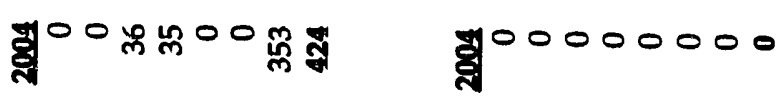

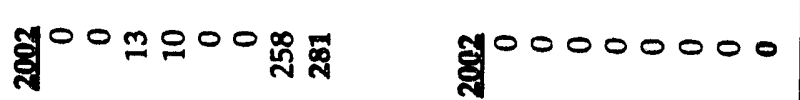
웡 $00000 \mathrm{~g}$ 웡 00000000 \%영 \%000000 解 : 00000000 $\$ 00000000$ :

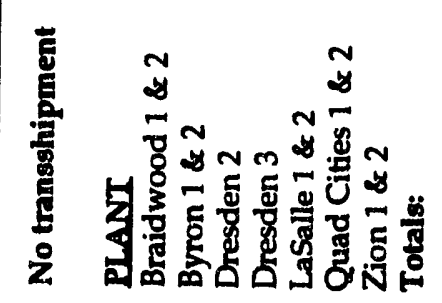

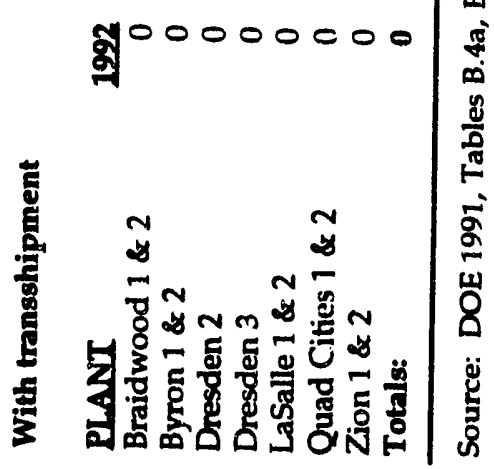


Appendix 5. DOE Cost Estimates for Methods of Interim Storage $e^{35}$

A. Unit-cost range for consolidating spent fuel for in-pool storage ${ }^{a}$

\begin{tabular}{|c|c|c|c|c|}
\hline \multirow[b]{2}{*}{ Factor } & \multicolumn{2}{|c|}{ Low Cost } & \multicolumn{2}{|c|}{ High Cost } \\
\hline & Fixed & Variable & Fixed & Variable \\
\hline NRC licensing & $\$ 200,000$ & & $\$ 500,000$ & \\
\hline Equipment and installation & $\$ 1,500,000$ & & $\$ 2,500,000$ & \\
\hline \multicolumn{5}{|l|}{ Operating laborb } \\
\hline PWR fuel & & 5 & & 7 \\
\hline BWR fuel & & 6 & & 8 \\
\hline \multicolumn{5}{|l|}{ Cost of canisters ${ }^{c}$} \\
\hline PWR fuel & & $\$ 2400$ & & $\$ 3600$ \\
\hline BWR fuel & & $\$ 1800$ & & $\$ 2700$ \\
\hline \multicolumn{5}{|l|}{ Total costs } \\
\hline Total fixed cost & $\$ 1,700,000$ & & $\$ 3,000,000$ & \\
\hline Total variable costs & & & & \\
\hline $\begin{array}{l}\text { Per kilogram of heavy } \\
\text { metal consolidated }\end{array}$ & & & & \\
\hline PWR fuel & & 8 & & 12 \\
\hline BWR fuel & & 12 & & 15 \\
\hline Weighted average & & 9 & & 14 \\
\hline Per kilogram of heavy & & & & \\
\hline metal gained & & & & \\
\hline PWR fuel & & 20 & & 34 \\
\hline BWR fuel & & 34 & & 60 \\
\hline Weighted average & & 25 & & 43 \\
\hline
\end{tabular}

acost estimates are not based on full-scale demonstration projects and are therefore somewhat speculative.

'Cost per kilogram of heavy metal.

'Cost per canister.

Source: DOE 1989a, Table 4-4.

3'DOE's 1989 Final Dry Cask Sturage Study serves as the source for the cost estimates associated with dry storage. Cost estimates are provided to give the reader an idea of the financial investment utilities must make to provide additional storage capacity for spent fuel. It should be noted, however, that these cost estimates were developed at a time when only two ISFSIs were operating. Since that time, three additional facilities have been licensed.

According to the Edison Electric Institute, DOE's high-end estimates for licensing and for storage facility fixed costs are low by approximately a factor of two. Similarly, DOE's estimates for cask loading and placing may be low by a factor of two. 
B. Unit-cost range for storing intact spent fuel in concrete modules

\begin{tabular}{|c|c|c|c|c|}
\hline \multirow{6}{*}{$\begin{array}{l}\text { Factor } \\
\text { NRC licensing } \\
\text { Storage facility (fixed cost) } \\
\text { Transfer cask with a } \\
\text { hydraulic-ram system* } \\
\text { Overall variable cost }\end{array}$} & \multicolumn{2}{|c|}{ Low Cost } & \multicolumn{2}{|c|}{ High Cost } \\
\hline & Fixed & Variable & Fixed & Variable \\
\hline & $\$ 300,000$ & & $\$ 1,000,000$ & \\
\hline & $\$ 500,000$ & & $\$ 1,000,000$ & \\
\hline & $\$ 1,000,000$ & & $\$ 1,000,000$ & \\
\hline & & 40 & & 50 \\
\hline Total costs & & & & \\
\hline $\begin{array}{l}\text { Total fixed cost } \\
\text { Total variable cost }\end{array}$ & $\$ 1,800,000$ & 40 & $\$ 3,000,000$ & 50 \\
\hline
\end{tabular}

a Cost estimates for transfer cask and hydraulic-ram system were based on the NUHOMS-7P system, therefore costs for the larger NUHOMS-24P system are likely to be higher.

bCost in dollars per kilogram of heavy metal.

Source: DOE 1989a, Table 4-3.

C. Unit-cost range for storing intact spent fuel in metal storage casks

\begin{tabular}{|c|c|c|c|c|}
\hline \multirow{3}{*}{$\begin{array}{l}\text { Factor } \\
\text { NRC licensing }\end{array}$} & \multicolumn{2}{|c|}{ Low Cost } & \multicolumn{2}{|c|}{ High Cost } \\
\hline & Fixed & Variable & Fixed & Variable \\
\hline & $\$ 300,000$ & & $\$ 1,000,000$ & \\
\hline \multicolumn{5}{|l|}{ Storage facility } \\
\hline Fixed cost & $\$ 500,000$ & & $\$ 1,000,000$ & \\
\hline Variable cost & & 2 & & 3 \\
\hline Cask costs" & & 50 & & 90 \\
\hline Loading and placing the cask ${ }^{a b}$ & & 1 & & 2 \\
\hline Unloading the cask ${ }^{2}$ & & 1 & & 2 \\
\hline \multicolumn{5}{|l|}{ Total costs } \\
\hline Total fixed cost & $\$ 800,000$ & & $\$ 2,000,000$ & \\
\hline Total variable cost" & & 54 & & 97 \\
\hline
\end{tabular}

a Cost in dollars per kilogram of heavy metal.

bWet loading is assumed.

Source: DOE 1989a, Table 4-1. 
D. Unit-cost range for storing intact spent fuel in concrete storage casks

\begin{tabular}{|c|c|c|c|c|}
\hline \multirow[b]{2}{*}{$\begin{array}{l}\text { Factor } \\
\text { NRC licensing }\end{array}$} & \multicolumn{2}{|c|}{ Low Cost } & \multicolumn{2}{|c|}{ Hiph Cost } \\
\hline & $\begin{array}{c}\text { Fixed } \\
\$ 300,000\end{array}$ & Variable & $\begin{array}{c}\text { Fixed } \\
\$ 1,000,000\end{array}$ & Variable \\
\hline Fixed cost & $\$ 500,000$ & & $\$ 1,000,000$ & \\
\hline Variable cost & & 2 & & 3 \\
\hline \multicolumn{5}{|l|}{ Dry-loading equipment } \\
\hline $\begin{array}{l}\text { Fixed cost } \\
\text { Variable cost. }\end{array}$ & & & $\$ 250,000$ & 3 \\
\hline Fixed cost & & & $\$ 250,000$ & \\
\hline Variable cost & & & & 3 \\
\hline \multicolumn{5}{|l|}{ Canning cost for dry loading } \\
\hline Fixed cost & & & $\$ 150,000$ & \\
\hline Variable cost" & & & & 10 \\
\hline Cask costs & & 40 & & 61 \\
\hline Loading and placing the cask" & & 1 & & 4 \\
\hline Unloading the cask & & 1 & & 4 \\
\hline \multicolumn{5}{|l|}{ Total costs } \\
\hline Total fixed cost & $\$ 800,000$ & & $\$ 2,400,000$ & \\
\hline Total variable cost & & 44 & & 85 \\
\hline
\end{tabular}

Cost in dollars per kilogram of heavy metal.

bAccording to the Edison Electric Institute, the variable costs for concrete cask systems being developed today are similar to the variable costs for concrete modules.

Source: DOE 1989a, Table 4-2. 


\title{
Midwestern High-Level Radioactive Waste Transportation Project
}

\author{
Publication Order Form
}

To order publications, indicate the quantity of each document you wish to receive, complete name and address information below, and return this form to:

\author{
Lisa R. Sattler \\ Midwestern Office of the Council of State Governments \\ 641 E. Butterfield Road, Suite 401 \\ Lombard, IL 60148-5651 \\ $708 / 810-0145$ (fax)
}

Name:

Title:

Company:

Address:

Phone:

Fax:

Midwestern Radiological Emergency Preparedness and Response Agency Report, May 1990, 43 pages, DOE/CH/10402--2. For twelve Midwestern states, this document reports on state agencies with emergency preparedness and response duties, providing specific information on radiological emergency response plans, agency responsibilities, contacts at the state level, and inventories of equipment for use during a radiological emergency.

Radioactive Materials Transportation Safety Training Report, May 1990, 16 pages, $\mathrm{DOE} / \mathrm{CH} / 10402-3$. This report looks at Midwestern state programs for training emergency response personnel to handle transportation accidents involving radioactive materials.

Report on Mutual Aid Agreements for Radiological Transportation Emergencies, May 1990, 10 pages, DOE/CH/10402--4. This report looks at existing interstate emengency response mutual aid agreements in the Northeast, South and West, and examines how similar

agreements among Midwestern states may facilitate emergency response to transportation accidents involving radioactive materials.

Model State Mutual Aid Agreement, December 1990, 6 pages, DOE/CH/10402-5. This document frovides a model of a state mutual aid agreement to serve as a starting point for discussion jetween Midwestern state officials interested in forming such an agreement for transportation emergencles involving radioactive materials.

Midwestern High-Leoel Radioactive Waste Transportation Primer, May 1991, 108 pages, DOE/CH/10402-9. A major milestone for the Transportation Project, the Primer discusses the objectives and challenges to implementing the federal Nuclear Waste Policy Act, with a focus on the Institutional issues surrounding the transportation of spent nuclear fuel and high-level radioactive waste. 
Midwestern States Highway Routing Report, November 1991, 16 pages, DOE/CH/10402--10. This report identifies those agencies in Midwestern states that hold specific authority to designate alternatives to the preferred routes established under federal guidelines for transporting high-level radioactive waste.

Timing and Funding of Emergency Response Training in Midwestern States, November 1991, 14 pages, DOE/CH/10402--14. By providing information on critical lead times for planning and delivering emergency response training courses in Midwestern states, this report provides a basis for determining the appropriate time to begin federal training assistance mandated by the Nuclear Waste Policy Act.

Highway Infrastructure Report, February 1992, 26 pages, DOE/CH/10402--16. This document compiles information on recent or planned state- and county-sponsored work projects targeting roads near nuclear power plants in the Midwest.

Handbook of High-Level Radioactive Waste Transportation, October 1992, 44 pages, DOE/CH/10402--19. This document condenses and updates information first presented in the Midwestern Primer of High-Level Radioactive Waste Transportation. The Handbook serves as a reference to which state officials and the general public may turn for information regarding radioactive waste transportation and the federal Civilian Radioactive Waste Management Program.

Report on Interim Storage of Spent Nuclear Fuel, April 1993, 34 pages, DOE/CH/10402-22. This report discusses the technical, regulatory, and economic aspects of spent-fuel storage at nuclear reactors, and is intended to provide legislators, state officials, and citizens in the Midwest with information on spent-fuel inventories, current and projected additional storage requirements, licensing, storage technologies, and actions taken by various utilities in the Midwest to augment their capacity to store spent nuclear fuel on site. 


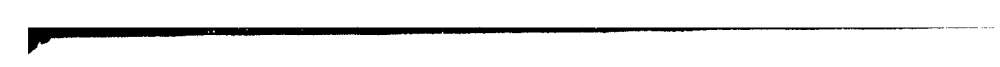

$\nabla$
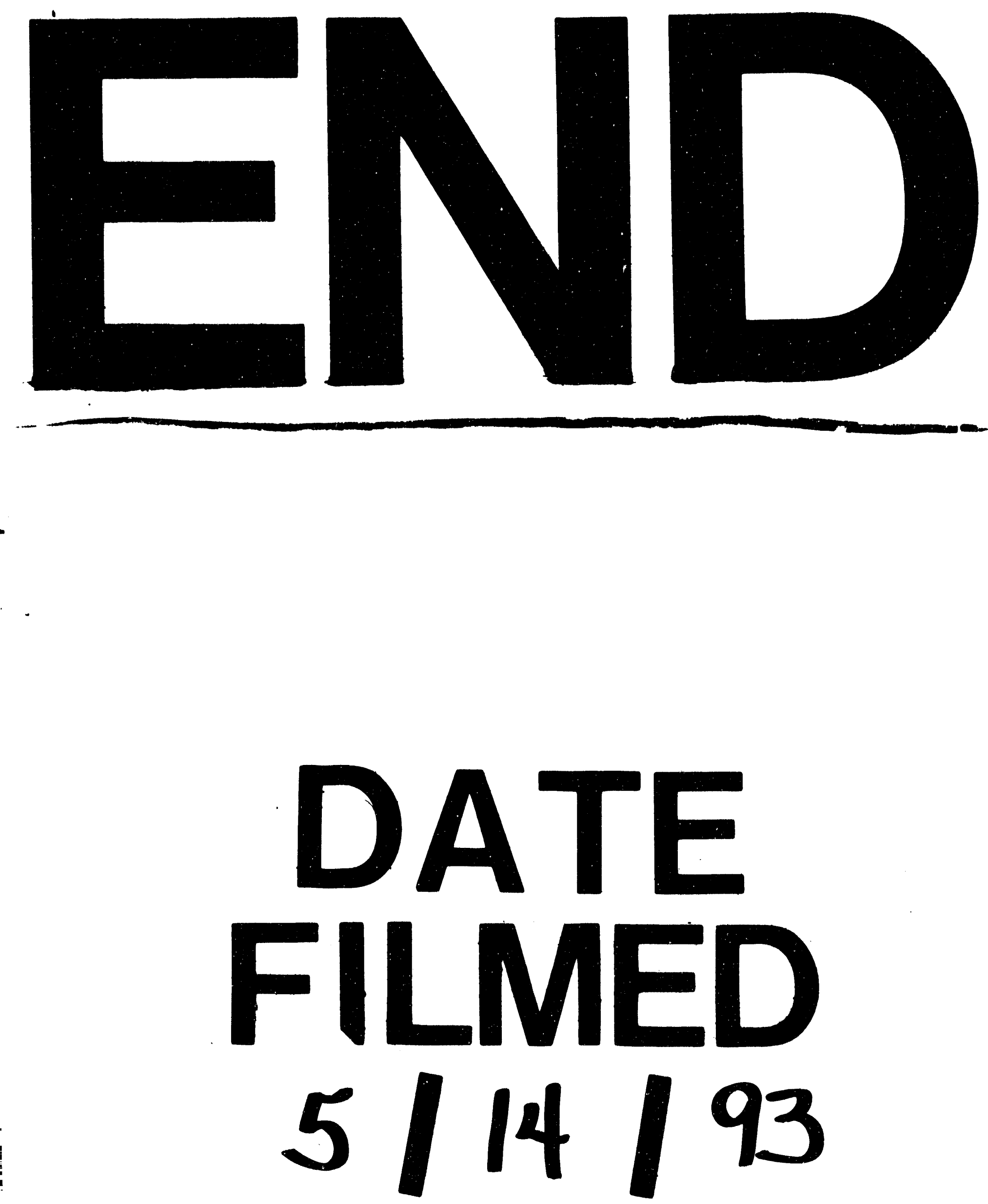

93 
